\title{
THE EFFECTS OF FRAME DEFORMATION ON WELDED GUSSET PLATES FOR DIAGONAL BRACING ELEMENTS LOADED IN TENSION
}

\author{
J. Kent Hsiao ${ }^{1, *}$, Donald W. Tempinson ${ }^{2}$ and Jianming $\mathrm{Li}^{3}$ \\ ${ }^{1}$ Associate Professor, Department of Civil and Environmental Engineering, \\ Southern Illinois University Carbondale, Carbondale, IL, USA \\ ${ }^{2}$ Former Graduate Student, Department of Civil and Environmental Engineering, \\ Southern Illinois University Carbondale, Carbondale, IL, USA \\ ${ }^{3}$ Graduate Student, Department of Civil and Environmental Engineering, \\ Southern Illinois University Carbondale, Carbondale, IL, USA \\ *(Corresponding author: E-mail: hsiao@engr.siu.edu)
}

Received: 10 February 2012; Revised: 17 April 2012; Accepted: 27 April 2012

\begin{abstract}
The effects of frame deformation on a gusset plate in a braced frame can be defined as the increases in stress in the gusset plate caused by the deformations of the beams and the columns of the braced frame. The hand-calculated approach for the design of gusset plates for diagonal bracing elements loaded in tension has traditionally neglected the frame deformation effects. A design example for a brace-beam-column gusset plate connection using the traditional hand-calculated approach is given in this paper. Two finite element approaches (one neglects the effects of frame deformation on the gusset plate while the other one considers the effects) are used to investigate the adequacy of the gusset plate designed by the hand-calculated approach. This study concludes that frame deformation effects have caused the increases in the von Mises and the first-principal stresses located at the Whitmore section of the gusset plate, as well as the increase in the combined effects of the factored tension and shear forces at the gusset edges. The traditional hand-calculated approach which neglects the frame deformation effects, therefore, may result in an under-design of the gusset plate.
\end{abstract}

Keywords: Finite element method, Nonlinear analysis, Rigid frames, Stress concentration, Tensile strength, Welded connections, Yield stress

\section{INTRODUCTION}

Gusset plates are used to transmit the applied forces from main elements (beams and columns) to bracing elements and vice versa. Figures 1 and 2 illustrate examples of gusset plate connections for an eccentrically braced frame and a special concentrically braced frame [1]. Many research papers have addressed the analyses and designs of gusset plate connections [2, 3, 4]. The stresses distributed along the edges and/or at the Whitmore effective sections of the gusset plates were the major topics discussed in these papers.

When a bracing member is subjected to a compressive force, the gusset plate, which is connected to the bracing member, will be stressed in compression and shear. However, since the vertical main member is deflecting away from the bracing member (refer to the lower left-hand quarter portion of the braced frame shown in Figures 3(a) \& (b)), the angle between the vertical main member and the horizontal main member is enlarged. As a result, tensile stresses are also introduced to the gusset plate.

The effects of frame deformation on gusset plates for diagonal bracing elements loaded in compression were investigated by Cheng, Grondin, and Yam [5] using full-scale tests. Their tests found that the capacity of the gusset plate was reduced due to the effects of frame deformation on the gusset plate. 
Similarly, for a reverse condition, when a bracing member is subjected to a tensile force, the gusset plate, which is connected to the bracing member, will be stressed in tension and shear. However, since the vertical main member is deflecting toward the bracing member (refer to the lower left-hand quarter portion of the braced frame shown in Figures 3(c) \& (d)), the angle between the vertical main member and the horizontal main member is reduced. As a result, compressive stresses are also introduced to the gusset plate.

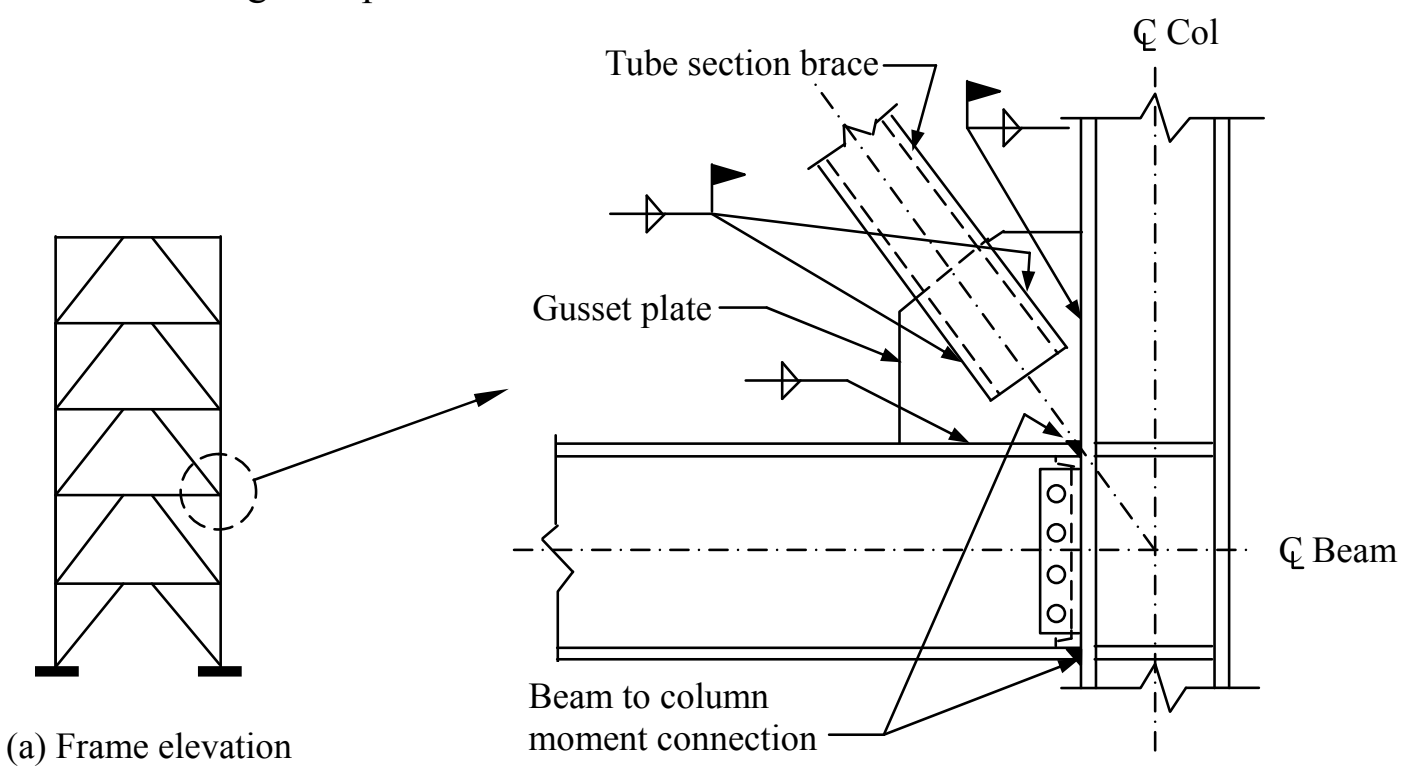

(b) Brace-beam-column connection

Figure 1. Gusset Plate Connection Example for an Eccentrically Braced Frame

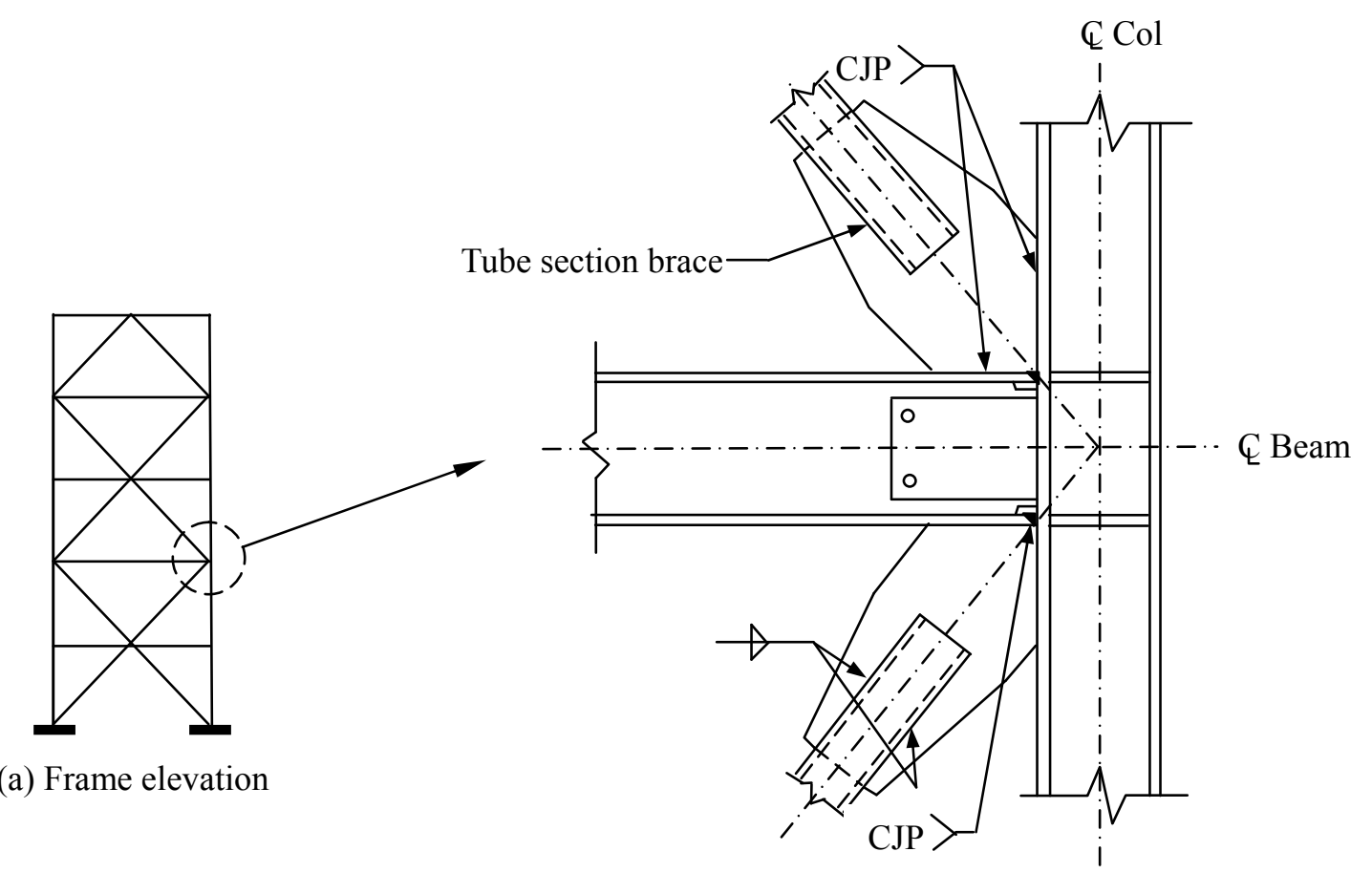

(b) Brace-beam-column connection

Figure 2. Gusset Plate Connection Example for a Special Concentrically Braced Frame 


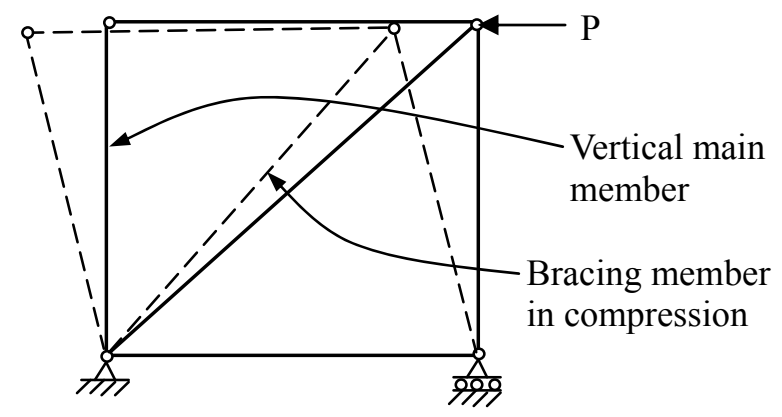

(a) Pinned-joint frame (bracing member in compression)

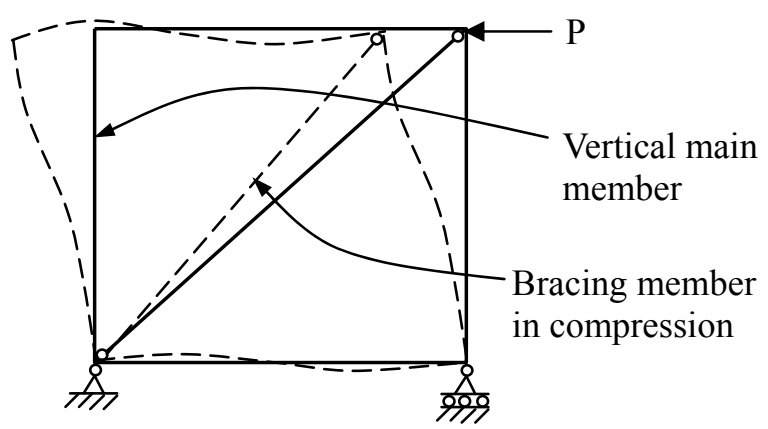

(b) Rigid-joint frame (bracing member in compression)

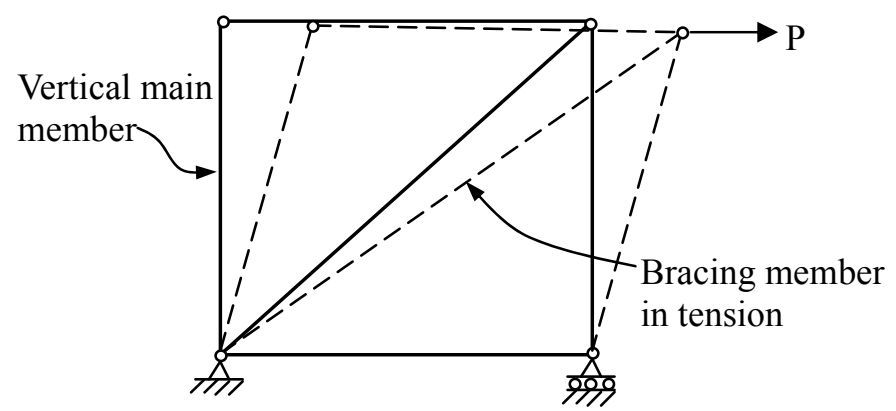

(c) Pinned-joint frame (bracing member in tension)

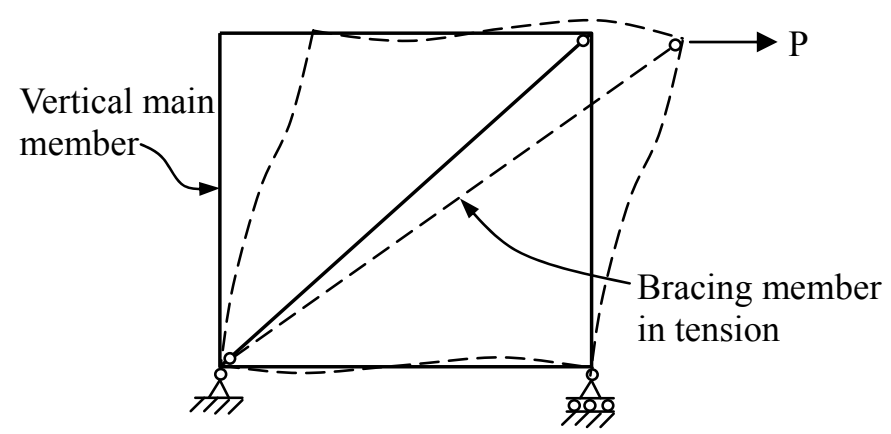

(d) Rigid-joint frame (bracing member in tension)

Figure 3. Deformations of Laterally Loaded Braced Frames

The effects of frame deformations on a welded gusset plate for a diagonal bracing element loaded in tension are investigated and the results are presented in this paper. This study is limited to the following conditions: (1) the gusset plate, the web of the beam (the horizontal member) and the 
web of the column (the vertical member) are in the same plane; (2) as shown in Figures 1 and 2, the beam (the horizontal member) is rigidly connected to the column (the vertical member); (3) the bracing element is welded to the gusset plates and is loaded in tension; and (4) fillet welds are used for the gusset-to-bracing element, gusset-to-beam, and gusset-to-column connections.

\section{DESIGN EXAMPLE OF A GUSSET PLATE CONNECTION FOR A DIAGONAL BRACING ELEMENT LOADED IN TENSION}

The following is a design example of a gusset plate connection for a diagonal bracing element loaded in tension. Two $\mathrm{C} 3 \times 6$ channels are used as the diagonal bracing element in a rigid frame as shown in Figure 4. ASTM A36 steel is used for the columns, beams, bracing member, and the gusset plates. Note that in the U.S., A992 steel is the preferred material for W shapes, while the availability of A36 should be confirmed prior to the use of it. Also, E70XX electrodes having a minimum tensile strength of $483 \mathrm{MPa}(70 \mathrm{ksi})$ are used for the fillet weld made by shielded metal arc welding (SMAW). Assume that the factored tensile force, $P_{u}$, applied to the bracing element is $507 \mathrm{kN}$ (114 kips).

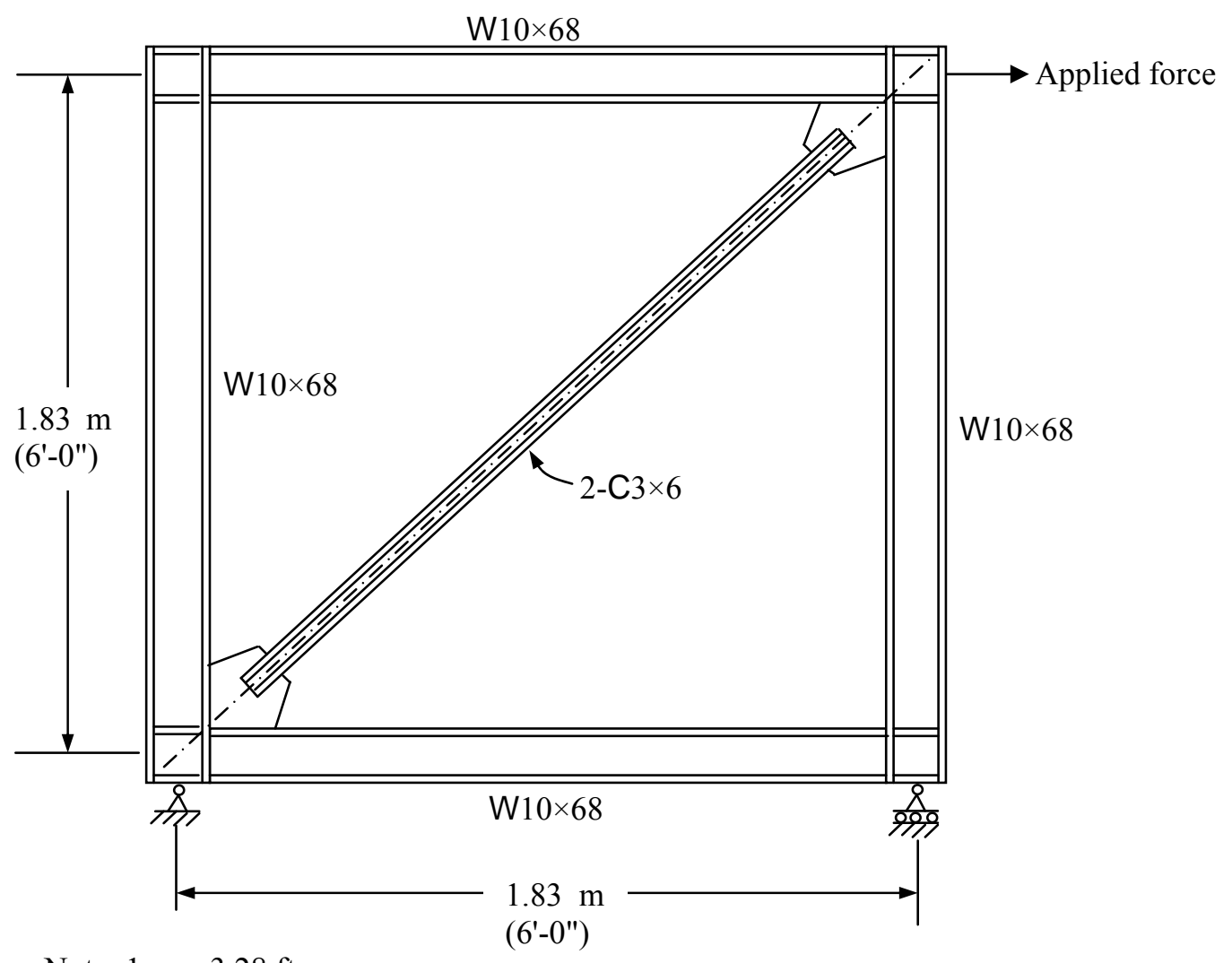

Note: $1 \mathrm{~m}=3.28 \mathrm{ft}$

Figure 4. Braced Frame Elevation

\section{Design of a gusset plate connection using the hand-calculated approach}

The following hand-calculated approach illustrates the use of the Whitmore section $[6,7]$ and the Uniform Force Method [1, 7, 8, 9] for the design of the gusset plate connection for the diagonal bracing element loaded in tension. 
1. Compute the design tensile strength of the bracing member [7]:

(a) For tensile yielding in the gross section:

$$
\phi_{t} P_{n}=\phi_{t} F_{y} A_{g}=0.9(248 \mathrm{MPa})\left(2270 \mathrm{~mm}^{2}\right)=507 \mathrm{kN}(114 \mathrm{kips}) \geq P_{u} \quad \text { o.k. }
$$

where $\phi_{t} P_{n}=$ design tensile strength; $F_{y}=$ specified minimum yield stress of the type of steel being used $\left[F_{y}=248 \mathrm{MPa}(36 \mathrm{ksi})\right.$ for A36 steel]; and $A_{g}=$ gross area of the bracing member $\left[A_{g}=2270 \mathrm{~mm}^{2}\left(3.52 \mathrm{in}^{2}\right)\right.$ for $\left.2-\mathrm{C} 3 \times 6\right]$.

(b) For tensile rupture in the net section:

$$
\begin{aligned}
& U=1-\frac{\bar{x}}{l}=1-\left(\frac{11.6}{200}\right)=0.942 \\
& \phi_{t} P_{n}=\phi_{t} F_{u} A_{n} U=0.75(400 \mathrm{MPa})\left(2270 \mathrm{~mm}^{2}\right)(0.942)=642 \mathrm{kN}(144 \mathrm{kips}) \geq P_{u} \quad \text { o.k. }
\end{aligned}
$$

where $U=$ reduction coefficient, used in calculating effective net area; $\bar{x}=$ horizontal distance from the outer edge of a channel web to its centroid; $l=$ length of the weld (assume that each weld length for the bracing element-to-gusset plate connection is $200 \mathrm{~mm}$ (8 in.); the assumed length will be verified in the following step); $\phi_{t} P_{n}=$ design tensile strength; $F_{u}$ $=$ specified minimum tensile strength of the type of steel being used $\left[F_{u}=400 \mathrm{MPa}\right.$ (58 ksi) for A36 steel]; and $A_{n}=$ net area.

2. Design the fillet weld for the bracing element-to-gusset plate connection:

In order to avoid brittle failure of connections, the capacity of the welded connection is recommended to be at least equal to or greater than the axial tension yield capacity of the bracing member determined using a conservative expected yield stress of $1.1 R_{y} F_{y}$ [4]. Therefore, the axial tension yield capacity of the bracing member $(2-\mathrm{C} 3 \times 6)$ can be computed as follows:

$$
1.1 R_{y} F_{y} A_{g}=1.1(1.5)(248 \mathrm{MPa})\left(2270 \mathrm{~mm}^{2}\right)=929 \mathrm{kN}(209 \mathrm{kips})
$$

where $R_{y}=$ ratio of the expected yield strength to the specified minimum yield strength of the grade of steel to be used $\left(R_{y}=1.5\right.$ for ASTM A36 steel channels [10]).

Using an $8 \mathrm{~mm}(5 / 16$ in.) fillet weld, the effective throat of the $8 \mathrm{~mm}(5 / 16$ in.) fillet weld is $t_{e}=(8 \mathrm{~mm})(0.707)=5.66 \mathrm{~mm}(0.22 \mathrm{in}$.

Therefore, the capacity of weld per inch can be computed as follows:

$$
0.75 t_{e}\left(0.60 F_{E X X}\right)=0.75(5.66 \mathrm{~mm})(0.60)(483 \mathrm{MPa})=1.23 \mathrm{kN} / \mathrm{mm}(7.0 \mathrm{kips} / \mathrm{in} .)
$$

Using a length of $200 \mathrm{~mm}(8 \mathrm{in}$.) for each fillet weld, since there are a total of four (4) 200 mm-long welds for the bracing element-to-gusset plate connection, the total welding capacity is $984 \mathrm{kN}(222 \mathrm{kips})(=4 \times 1.23 \mathrm{kN} / \mathrm{mm} \times 200 \mathrm{~mm})$, which is larger than $929 \mathrm{kN}$ (209 kips) (the axial tension yield capacity of the bracing member). Therefore, the capacity of the fillet weld for the bracing element-to-gusset plate connection is adequate. Figure 5 illustrates the fillet weld for the bracing element-to-gusset plate connection. 
3. Determine the thickness of the gusset plate using the Whitmore section:

In order to increase global ductility of a braced frame, yielding of the bracing member shall occur before the yielding of the gusset plate [4]. Therefore, the following equation is suggested for the determination of the gusset plate thickness:

$R_{y} F_{y} A_{g} \leq F_{y} A_{e}$

where $R_{y}=1.5$ for ASTM A36 steel; $F_{y}=248 \mathrm{MPa}(36 \mathrm{ksi})$ for ASTM A36 steel; $A_{g}=$ cross area of steel channels (bracing member); and $A_{e}=$ area of the Whitmore effective section of the gusset plate.

Referring to Figures 5 and 6, the Whitmore effective width [7] of the plate is:

$l_{w}=2(200 \mathrm{~mm})\left(\tan 30^{\circ}\right)+76 \mathrm{~mm}=307 \mathrm{~mm}(12.2 \mathrm{in}$.

Note that $76 \mathrm{~mm}$ ( $3 \mathrm{in}$.) is the depth of the $\mathrm{C} 3 \times 6$ channels. Therefore, the area of the Whitmore effective section can be computed as follows:

$A_{e}=\left(l_{w}\right)(t)=307 t \mathrm{~mm}^{2}\left(12.2 t\right.$ in. $\left.^{2}\right)$

Note that $t$ is the thickness of the gusset plate. From Eq. 1, one has

$1.5(248 \mathrm{MPa})\left(2270 \mathrm{~mm}^{2}\right) \leq 248 \mathrm{MPa}\left(307 t \mathrm{~mm}^{2}\right)$

[1.5 (36 ksi) $\left(3.52\right.$ in. $\left.^{2}\right) \leq 36 \mathrm{ksi}\left(12.2 t\right.$ in. $\left.\left.^{2}\right)\right]$

From which, the minimum required thickness $t=11.1 \mathrm{~mm}\left(0.43 \mathrm{in}\right.$.). Therefore, $12 \mathrm{~mm}\left({ }^{15} / 32\right.$ in.) is used for the thickness of the gusset plate.

4. Determine the configuration of the gusset plate:

The configuration of the gusset plate shown in Figure 5 was determined based on the following criteria: (1) A minimum length of $25 \mathrm{~mm}$ (1 in.) is provided on each side of the bracing element along the gusset plate edge, which is perpendicular to the diagonal bracing element. (2) Weld is terminated not less than one weld size from edge of the gusset plate. Since the weld size is $8 \mathrm{~mm}(5 / 16$ in.), $10 \mathrm{~mm} \mathrm{(3/8} \mathrm{in.)} \mathrm{is} \mathrm{provided} \mathrm{for} \mathrm{the} \mathrm{required} \mathrm{distance} \mathrm{as} \mathrm{shown} \mathrm{in} \mathrm{Figure} \mathrm{5.} \mathrm{(3)}$ The re-entrant corner of the gusset plate is located at the intersection of the face of the column (or the face of the beam) and the $30^{\circ}$ line as shown in Figures 5 and 6). (4) The distance from the end of the bracing element to the line that connects the two re-entrant corners is not less than two times the thickness of the gusset plate in order to ensure that the gusset plate can freely rotate when the bracing element is subjected to a compression force [4]. Since the thickness of the gusset plate is $12 \mathrm{~mm} \mathrm{(}{ }^{15} / 32 \mathrm{in}$.), $24 \mathrm{~mm} \mathrm{(}{ }^{15 / 16} \mathrm{in}$.) is provided for the required distance as shown in Figure 5. 


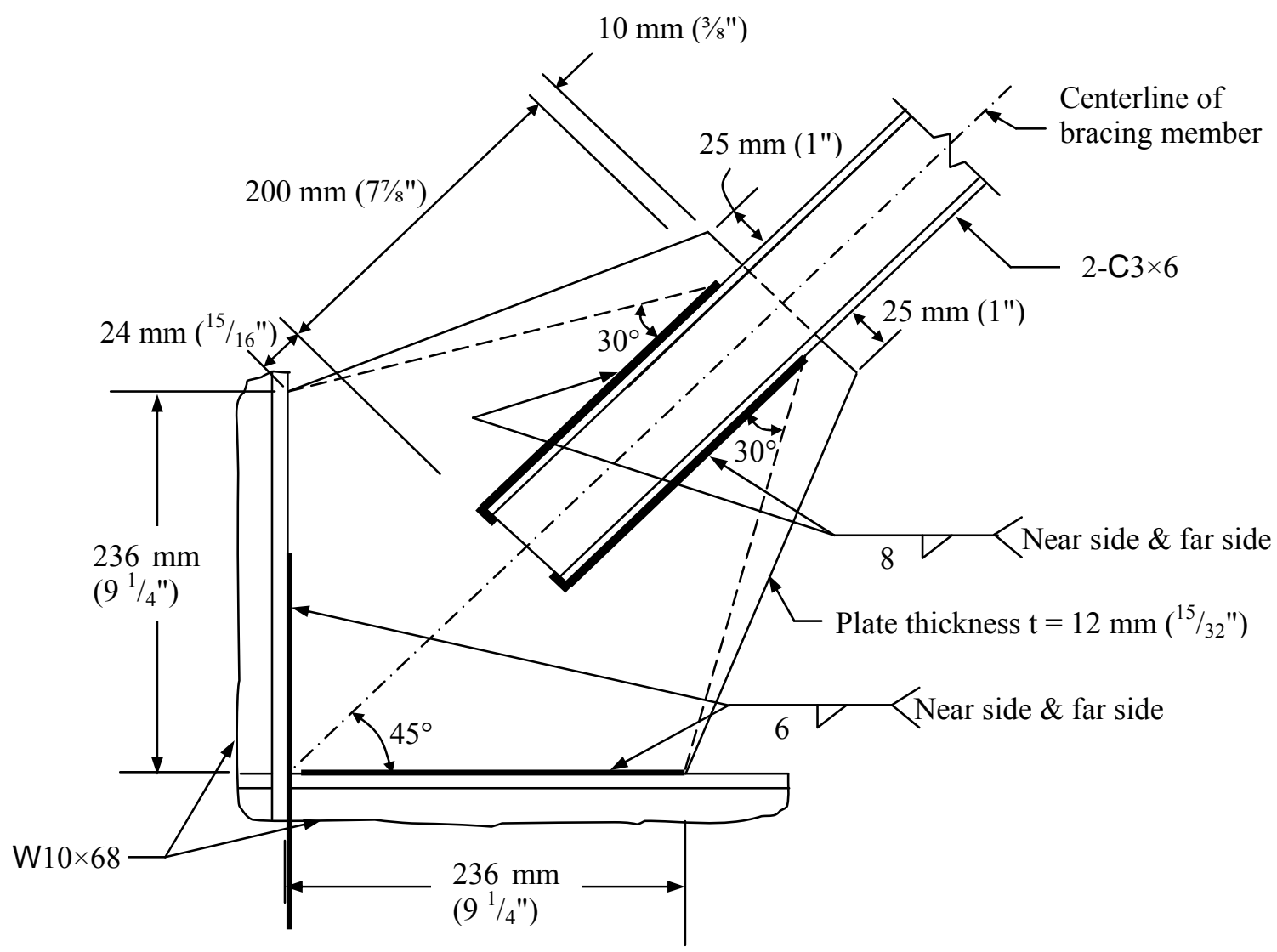

Note: $1 \mathrm{~mm}=0.0394$ in.

Figure 5. Gusset Plate Connection for a Diagonal Bracing Element

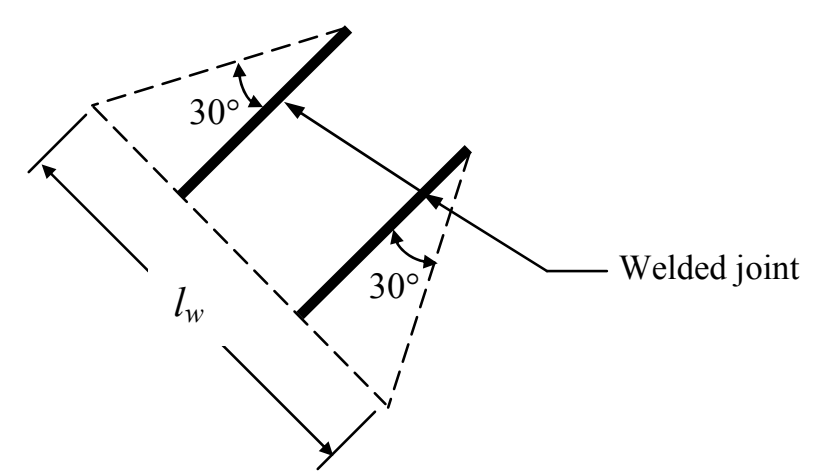

Figure 6. The Effective Width of the Whitmore Section for a Welded Joint

5. Determine the adequacy of the thickness of the gusset plate using the Uniform Force Method: Using the connection geometry shown in Figures 5 and 7, five geometric parameters $e_{b}, e_{c}, \alpha, \beta$, and $r$ can be determined as:

One-half the depth of the beam (the horizontal element W10 $\times 68), e_{b}=d_{b} / 2=(264 \mathrm{~mm}) / 2=132$ $\mathrm{mm}(5.2 \mathrm{in}$.). 


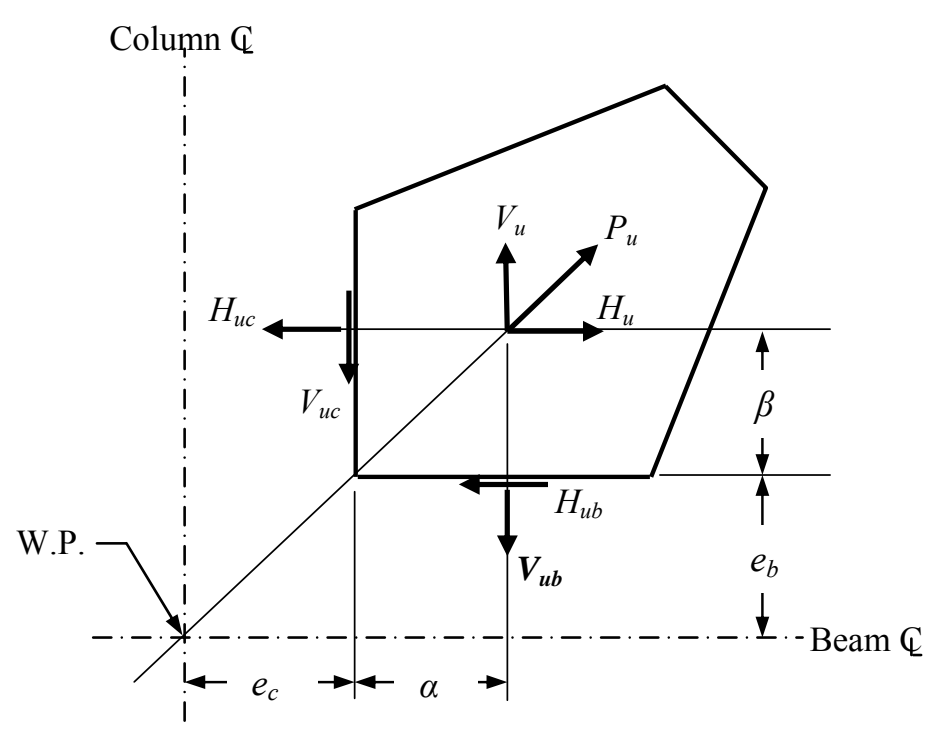

Figure 7. Gusset Plate Free-body Diagram

One-half the depth of the column (the vertical element W10 $\times 68), e_{c}=d_{c} / 2=(264 \mathrm{~mm}) / 2=132$ $\mathrm{mm}(5.2$ in.).

The distance from the face of the column flange to the centroid of the gusset-to-beam connection, $\alpha=118 \mathrm{~mm}$ (4.6 in.).

The distance from the face of the beam flange to the centroid of the gusset-to-column connection, $\beta=118 \mathrm{~mm}$ (4.6 in.).

The distance from the working point (as shown in Figure 7) to the centroid of the gusset plate connection,

$$
\begin{aligned}
r & =\sqrt{\left(\alpha+e_{c}\right)^{2}+\left(\beta+e_{b}\right)^{2}}=\sqrt{(118 \mathrm{~mm}+132 \mathrm{~mm})^{2}+(118 \mathrm{~mm}+132 \mathrm{~mm})^{2}} \\
& =354 \mathrm{~mm}(13.9 \text { in. })
\end{aligned}
$$

Therefore, the factored shear force at the gusset-to-column connection,

$V_{u c}=\frac{\beta}{r} P_{u}=\frac{118 \mathrm{~mm}}{354 \mathrm{~mm}}(507 \mathrm{kN})=169 \mathrm{kN}(38.0 \mathrm{kips})$

The factored axial force at the gusset-to-column connection,

$H_{u c}=\frac{e_{c}}{r} P_{u}=\frac{132 \mathrm{~mm}}{354 \mathrm{~mm}}(507 \mathrm{kN})=189 \mathrm{kN}(42.5 \mathrm{kips})$

The factored axial force at the gusset-to-beam connection, $V_{u b}=\frac{e_{b}}{r} P_{u}=\frac{132 \mathrm{~mm}}{354 \mathrm{~mm}}(507 \mathrm{kN})=189 \mathrm{kN}(42.5 \mathrm{kips})$ 
The factored shear force at the gusset-to-beam connection,

$H_{u b}=\frac{\alpha}{r} P_{u}=\frac{118 \mathrm{~mm}}{354 \mathrm{~mm}}(507 \mathrm{kN})=169 \mathrm{kN}(38.0 \mathrm{kips})$

The next step is to check the design strength at the horizontal and vertical edges of the gusset plate against the combined effects of the factored tension and shear forces using the von Mises yield criterion [1].

The combined effects of the factored tension and shear forces at the vertical edge of the gusset plate can be computed as follows:

$\mathrm{P}_{\mathrm{u}}=\sqrt{\mathrm{H}_{\mathrm{uc}}^{2}+3 \mathrm{~V}_{\mathrm{uc}}^{2}}=\sqrt{(189 \mathrm{kN})^{2}+3(169 \mathrm{kN})^{2}}=348 \mathrm{kN}(78.2 \mathrm{kips})$

The design strength at the vertical edge of the gusset plate is

$\phi P_{n}=\phi(2 \beta) t F_{y}=0.9(2 \times 118 \mathrm{~mm})(12 \mathrm{~mm})(248 \mathrm{MPa})=632 \mathrm{kN}(142.1 \mathrm{kips})$

Therefore, the design strength at the vertical edge is larger than the combined effects of the factored tension and shear forces.

The result at the horizontal edge of the gusset plate will be the same as that at the vertical edge of the gusset plate since the horizontal and vertical edges are symmetric about the diagonal bracing element.

The results shown above indicate that the thickness of the gusset plate is adequate.

6. Design the fillet weld for the gusset-to-W10 $\times 68$ flange connection using the Uniform Force Method:

Since $H_{u b}=169 \mathrm{kN}$ (38.0 kips), the shear force along the gusset-to-beam interface can be computed as follows:

$\mathrm{f}_{\mathrm{v}}=\frac{169 \mathrm{kN}}{236 \mathrm{~mm}}=0.716 \mathrm{kN} / \mathrm{mm}(4.09 \mathrm{kips} /$ in. $)$

Also, since $V_{u b}=189 \mathrm{kN}$, the tension force along the gusset-to-beam interface can be computed as follows:

$\mathrm{f}_{\mathrm{a}}=\frac{189 \mathrm{kN}}{236 \mathrm{~mm}}=0.801 \mathrm{kN} / \mathrm{mm}(4.57 \mathrm{kips} / \mathrm{in}$.

Furthermore, since there is no in-plane bending stress along the gusset-to-beam interface, $f_{b}=0$ $\mathrm{KN} / \mathrm{mm}$. Therefore, the peak and average forces at the gusset-to-beam interface [9] can be computed as follows:

$$
\begin{aligned}
& f_{\text {peak }}=\sqrt{f_{v}^{2}+\left(f_{a}+f_{b}\right)^{2}}=\sqrt{f_{v}^{2}+f_{a}^{2}}=1.074 \mathrm{kN} / \mathrm{mm}(6.13 \mathrm{kips} / \mathrm{in} .) \\
& f_{\text {avg }}=(1 / 2)\left(f_{\text {peak }}+\sqrt{f_{v}^{2}+\left(f_{a}-f_{b}\right)^{2}}\right)=\sqrt{f_{v}^{2}+f_{a}^{2}}=1.074 \mathrm{kN} / \mathrm{mm}(6.13 \mathrm{kips} / \mathrm{in} .)
\end{aligned}
$$


Note that when the gusset is directly welded to the beam or column, the connection should be designed for the larger of the peak stress and 1.25 times the average stress, but the weld size need not be larger than that required to develop the strength of the gusset [9]. Therefore, the connection should be designed for the stress of $1.343 \mathrm{kN} / \mathrm{mm}(7.67 \mathrm{kips} / \mathrm{in}$. $)(=1.25 \times 1.074$ $\mathrm{kN} / \mathrm{mm})$, but need not be larger than $2.678 \mathrm{kN} / \mathrm{mm}\left(15.2 \mathrm{kips} / \mathrm{in}\right.$.). Note that $\phi t F_{y}=0.9(12$ $\mathrm{mm})(248 \mathrm{MPa})=2.678 \mathrm{kN} / \mathrm{mm}\left(\phi t F_{y}=0.9(0.47 \mathrm{in}).(36 \mathrm{ksi})=15.2 \mathrm{kips} / \mathrm{in}.\right)$.

Using a $6 \mathrm{~mm}$ fillet weld, the design strength of the fillet weld for the gusset-to-beam (W10×68) flange connection can be computed as follows:

$$
\phi R_{n}=2 \times 0.75\left(0.6 F_{E X X} t_{e}\right)=2 \times 0.75\left[0.6 \times 0.483 \times \frac{\sqrt{2}}{2} \times 6\right]=1.844 \mathrm{kN} / \mathrm{mm} \quad(10.53 \mathrm{kips} / \mathrm{in} .)
$$

Since the design strength is larger than the required strength of $1.343 \mathrm{kN} / \mathrm{mm}$ (7.67 kips/in.), the horizontal fillet weld for the gusset-to-beam flange connection is adequate. The same approach can be repeated to determine the adequacy of the vertical fillet weld for the gusset-to-column flange connection.

Figure 5 summarizes the results of the above hand-calculated approach. Note that the hand-calculated approach neglects the effects of frame deformation on the gusset plate.

\section{INVESTIGATION OF GUSSET PLATE CONNECTION USING FINITE ELEMENT METHOD}

The following investigation procedure illustrates the use of the finite element method for the determination of the adequacy of the gusset plate connection, which was designed using the hand-calculated approach presented above. Nonlinear static analyses have been conducted using the computer software NISA/DISPLAY [11] for the finite element approaches. The elastic, linear hardening stress-strain curve (derived from Salmon et al. [12]), with $F_{y}=248 \mathrm{MPa}$ (36 ksi), corresponding to a strain of $0.00124 \mathrm{~mm} / \mathrm{mm}$ (in./in.) and $F_{u}=400 \mathrm{MPa}(58 \mathrm{ksi})$, corresponding to a strain of $0.185 \mathrm{~mm} / \mathrm{mm}$ (in./in.), has been used as the material property for the A36 steel. Assuming that the E7018 electrode was used for the fillet weld, the elastic, linear hardening stress-strain curve (derived from the Lincoln Electric Company [13]), with $F_{y}=448 \mathrm{MPa}$ (65 ksi), corresponding to a strain of $0.00224 \mathrm{~mm} / \mathrm{mm}$ (in./in.) and $F_{u}=510 \mathrm{MPa}(74 \mathrm{ksi})$, corresponding to a strain of $0.15 \mathrm{~mm} / \mathrm{mm}$ (in./in.), has been used as the material property for the fillet weld. In the strain-hardening range, the stress again increases and continues up to the tensile strength. In this paper, the elastic, linear hardening stress-strain curves were used in order to conduct the nonlinear static finite element analyses, as well as to determine the actual location of the maximum first-principal stress (which is related to the occurrence of fracture if the stress reaches the tensile strength, the limiting value in tension) in the gusset plate. Two approaches have been used for the investigation; one neglects the effects of frame deformation on the gusset plate while the other one considers the effects. 
Finite element approach I - neglecting the effects of frame deformation on the gusset plate:

The lower left-hand quarter portion of the braced frame shown in Figure 4 was used for the development of the finite element model as shown in Figure 8. The model was made of 3-D solid elements. A pinned condition was used at the free end of the beam and column as well as at the base of the gusset-beam-column connection. In this model, an additional plate was added to the base of the gusset-beam-column connection in order to mitigate the stress concentration caused by the pinned support [Figure 8(a)].

A load increment was applied at the end of the bracing element. As the load gradually increased, the stress concentration gradually accumulated at the end of the welded joint, as well as at the start of the welded joint (Figures 9, 10, and 11). When the load applied to the bracing element reached $507 \mathrm{kN}$ (114 kips), as shown in Figure 8(b), the von Mises stress reached $215 \mathrm{MPa}$ (31.2 ksi) and $286 \mathrm{MPa}(41.5 \mathrm{ksi})$ at the end of the welded joint and the start of the welded joint, respectively, as shown in Figure 10. Meanwhile, the first-principal stress reached $223 \mathrm{MPa}$ (32.3 ksi) and 219 $\mathrm{MPa}(31.8 \mathrm{ksi})$ at the end of the welded joint and the start of the welded joint, respectively, as shown in Figure 11.

The above results indicate that when the load applied to the bracing element reaches $507 \mathrm{kN}(114$ kips), the maximum von Mises stress located at the start of the welded joint reaches $286 \mathrm{MPa}$ (41.5 $\mathrm{ksi}$ ), which is larger than $248 \mathrm{MPa}$ (36 ksi) (the specified minimum yield stress of the A36 steel). Therefore, yielding is expected to initiate at the start of the welded joint. However, since the maximum first-principal stress, $223 \mathrm{MPa}(32.3 \mathrm{ksi})$, located at the end of the welded joint is less than $400 \mathrm{MPa}$ (= $58 \mathrm{ksi}$, the specified minimum tensile strength of the A36 steel), fracturing is not expected to happen in the gusset plate.

Moreover, when the load applied to the bracing element reaches $507 \mathrm{kN}$ (114 kips), the shear stress $\left(\mathrm{S}_{\mathrm{xy}}\right)$ distributions along the gusset edges are shown in Figure 12, the normal stress $\left(\mathrm{S}_{\mathrm{xx}}\right)$ distribution along the vertical gusset edge is shown in Figure 13, and the normal stress $\left(S_{\mathrm{yy}}\right)$ distribution along the horizontal gusset edge is shown in Figure 14. The resultant forces for the shear and tensile stresses are shown in Figure 15.

Figure 15 indicates that the resultant shear force acting along the horizontal and vertical gusset edges is $177 \mathrm{kN}$ (39.8 kips), which is about 5\% larger than that obtained from the hand-calculated approach (169 kN (38.0 kips)), as shown in the design example. Also, the resultant tensile force acting on the horizontal and vertical edges is $181 \mathrm{kN}$ (40.7 kips), which is about $4 \%$ less than that obtained from the hand-calculated approach (189 kN (42.5 kips)), as shown in the design example.

Figure 15 also indicates that the resultant tensile force acting on the horizontal gusset edge is located outside the distance ' $\alpha$ ' (the distance from the face of the column flange to the centroid of the gusset-to-beam connection) and the resultant tensile force acting on the vertical gusset edge is located outside the distance ' $\beta$ ' (the distance from the face of the beam flange to the centroid of the gusset-to-column connection). Note that as shown in Figure 7, the hand-calculated approach assumes that the resultant tensile force $\left(V_{u b}\right)$ acting on the horizontal gusset edge is located at the centroid of the gusset-to-beam connection, while the resultant tensile force $\left(H_{u c}\right)$ acting on the vertical gusset edge is located at the centroid of the gusset-to-column connection. 


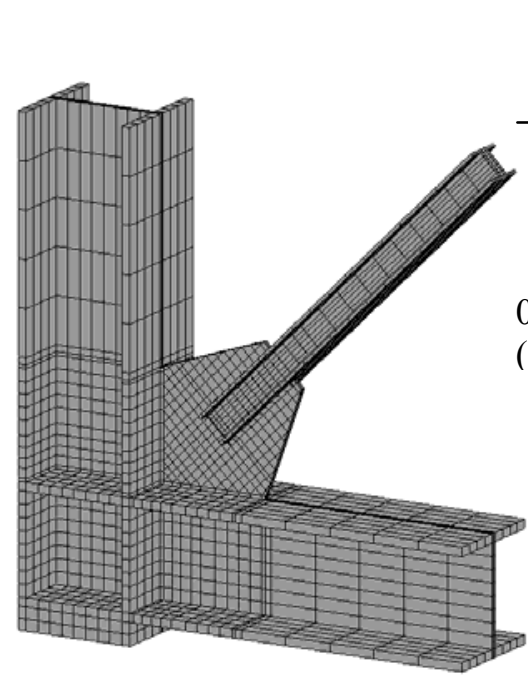

(a) Computer model

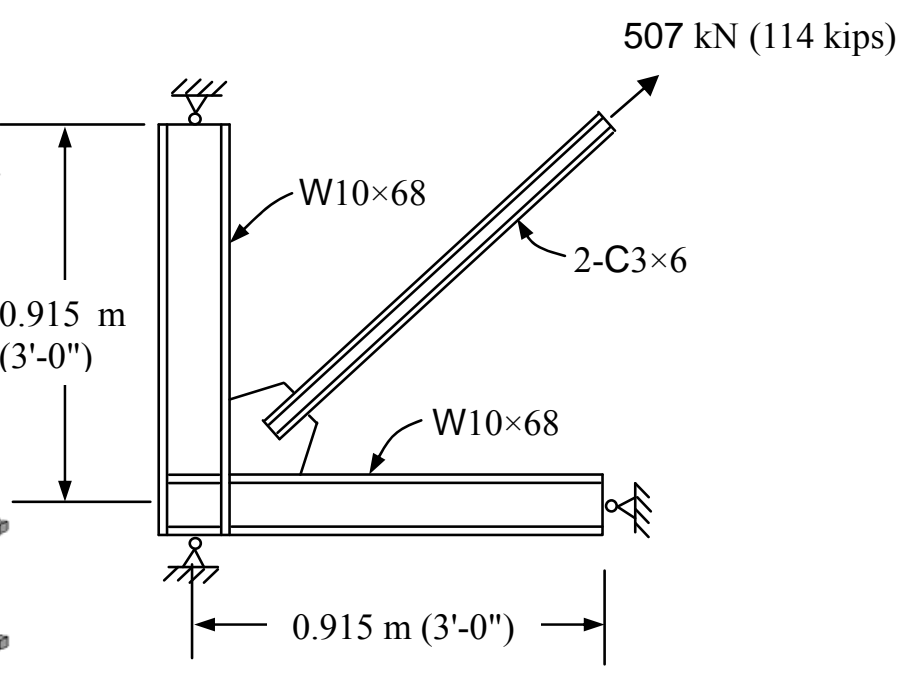

(b) Boundary condition of the model

Notes: $1 \mathrm{~m}=3.28 \mathrm{ft} ; 1 \mathrm{kN}=0.2248$ kips

Figure 8. Finite Element Model Neglecting Frame Deformation Effects

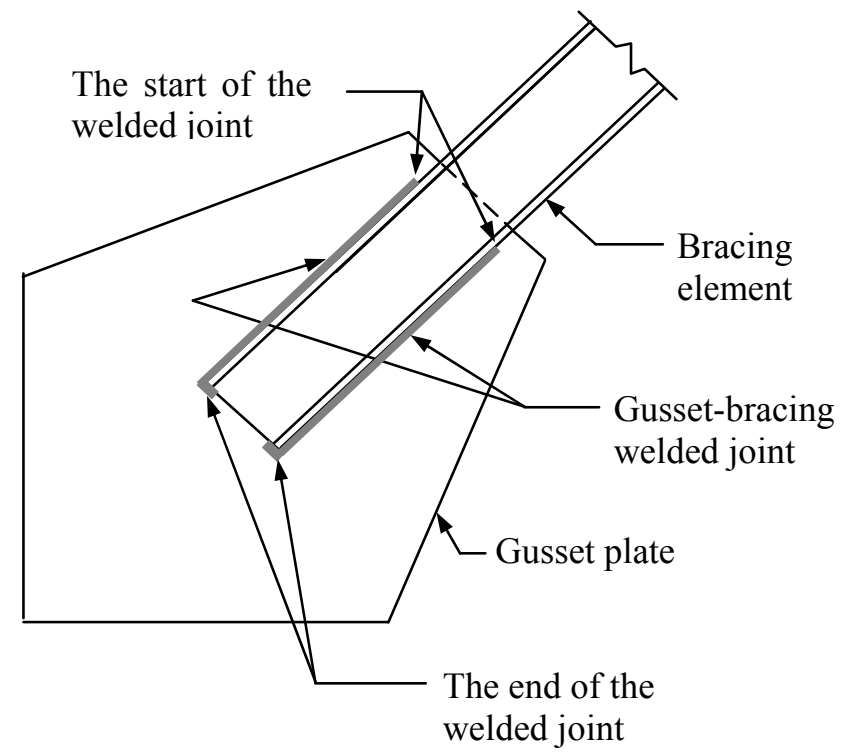

Figure 9. Gusset Plate-bracing Element Welded Joint 

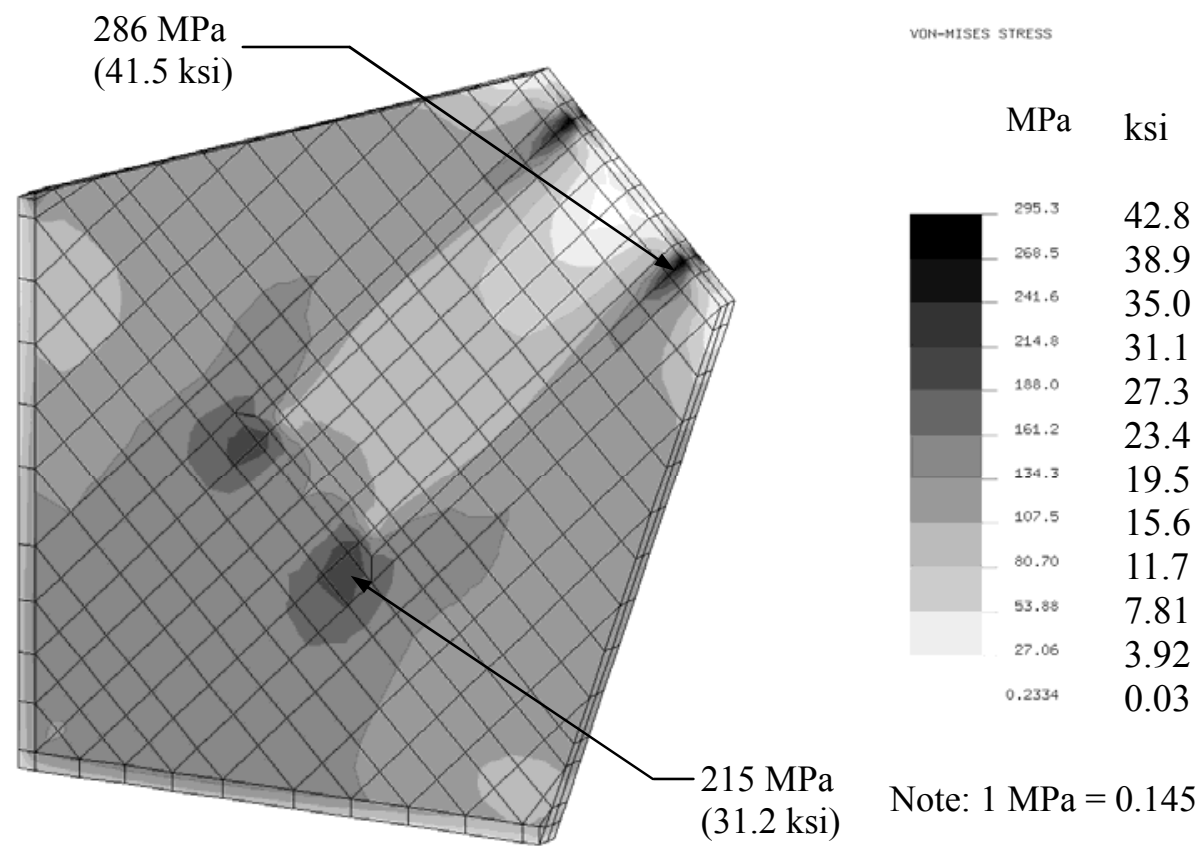

Note: $1 \mathrm{MPa}=0.145 \mathrm{ksi}$

Figure 10. Von Mises Stress Distribution on Gusset Plate Neglecting Frame Deformation Effects
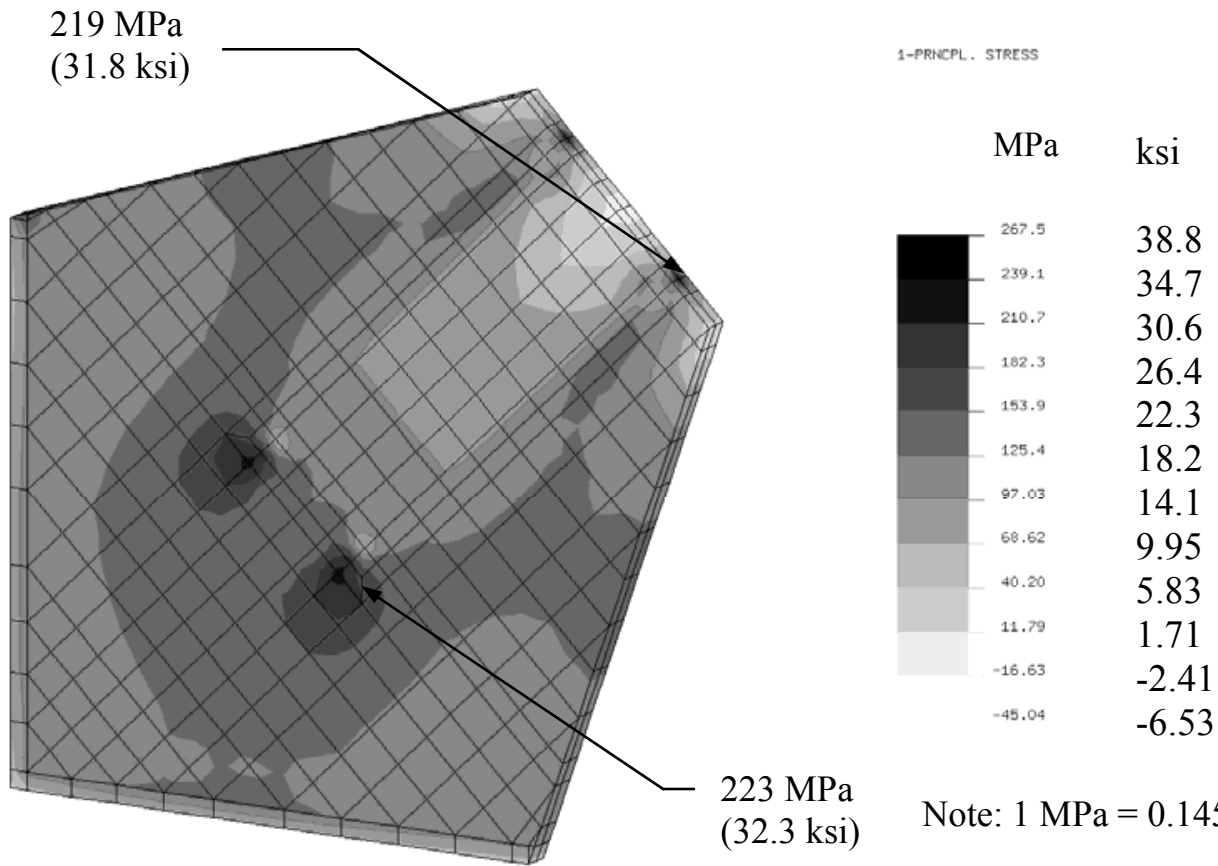

Note: $1 \mathrm{MPa}=0.145 \mathrm{ksi}$

Figure 11. First-principal Stress Distribution on Gusset Plate Neglecting Frame Deformation Effects 

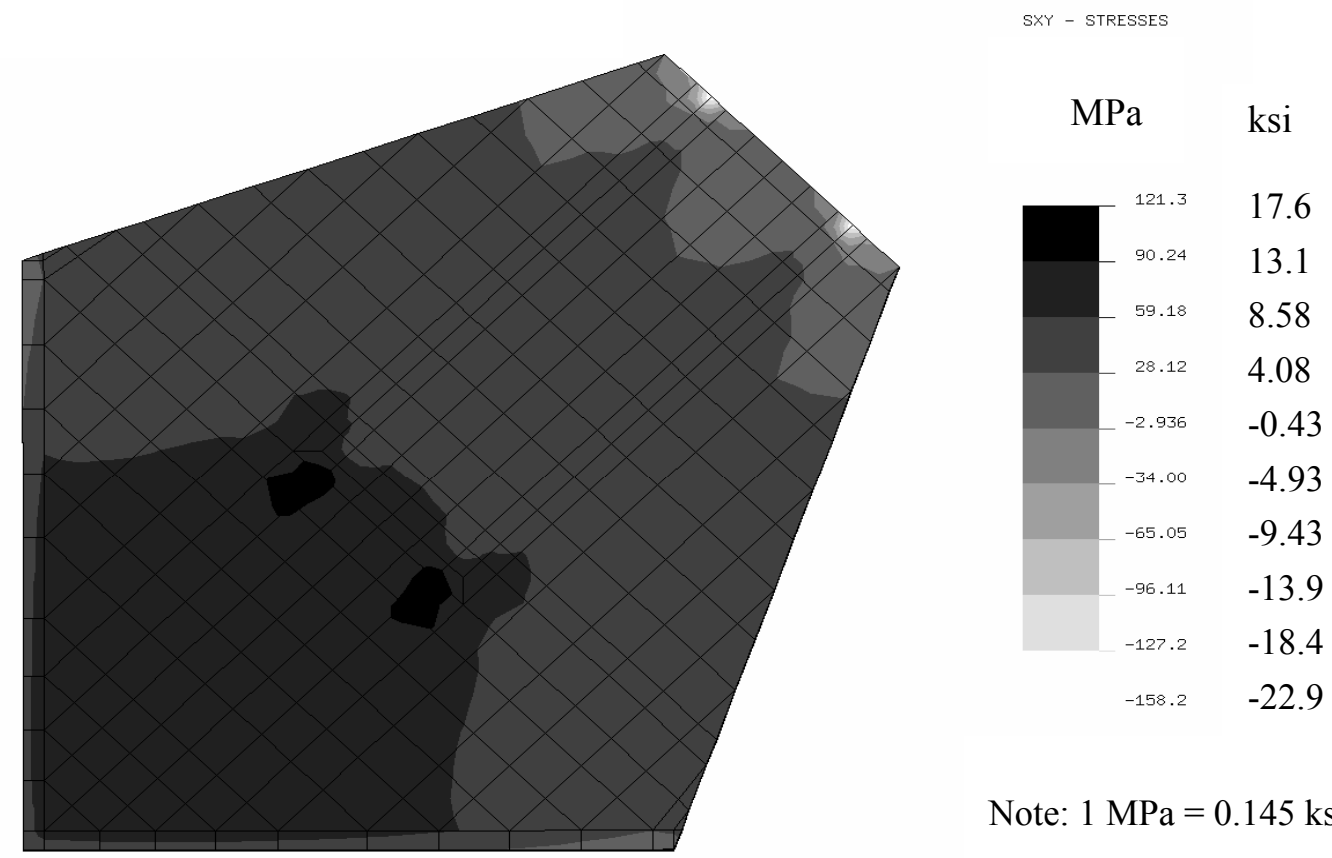

Figure 12. Shear Stress Distributions on Gusset Edges Neglecting Frame Deformation Effects

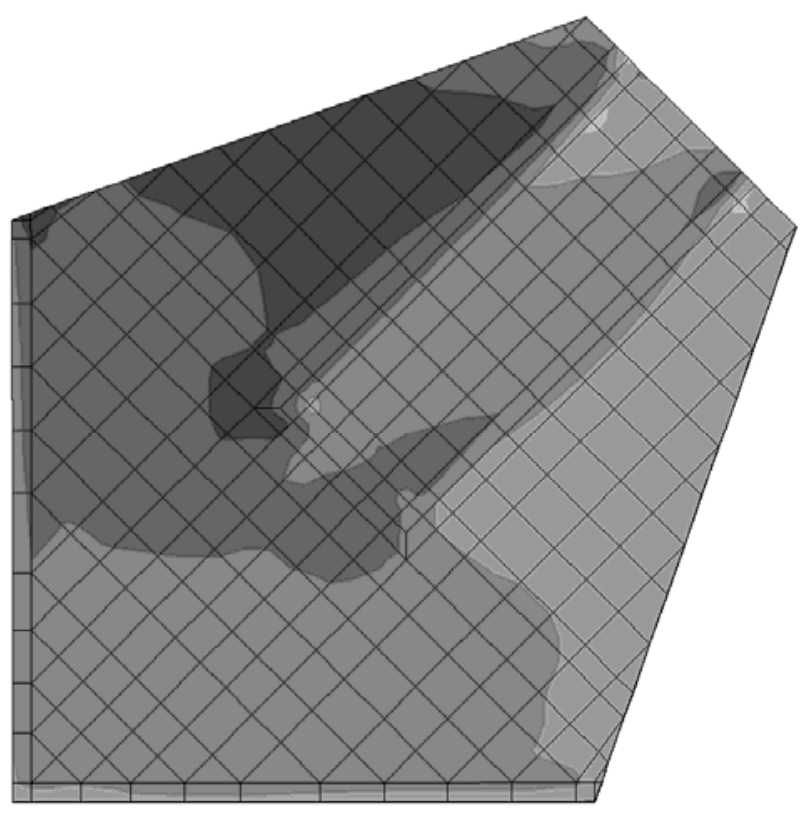

Note: $1 \mathrm{MPa}=0.145 \mathrm{ksi}$

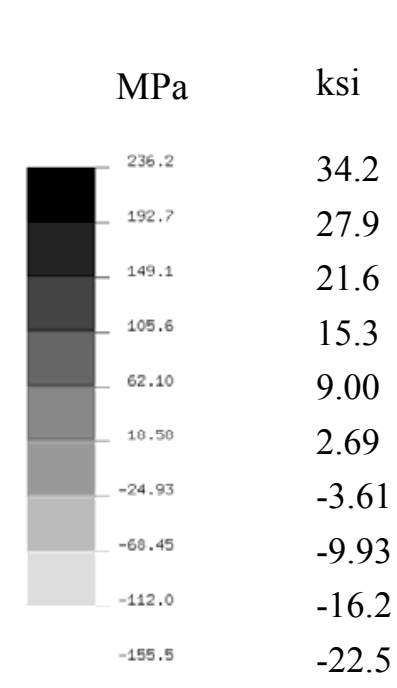

Note: $1 \mathrm{MPa}=0.145 \mathrm{ksi}$

Figure 13. Normal Stress Distribution on Vertical Gusset Edge Neglecting Frame Deformation Effects 

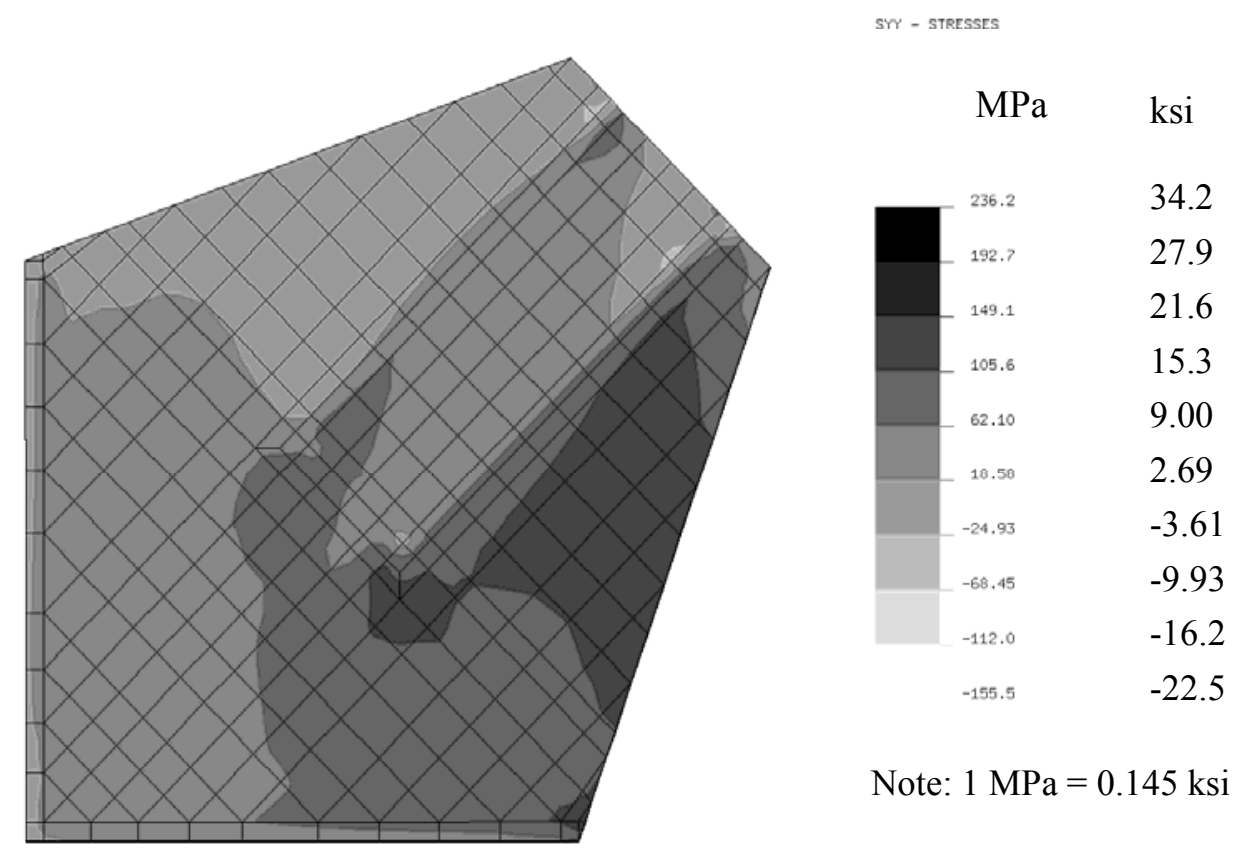

Figure 14. Normal Stress Distribution on

Horizontal Gusset Edge Neglecting Frame Deformation Effects

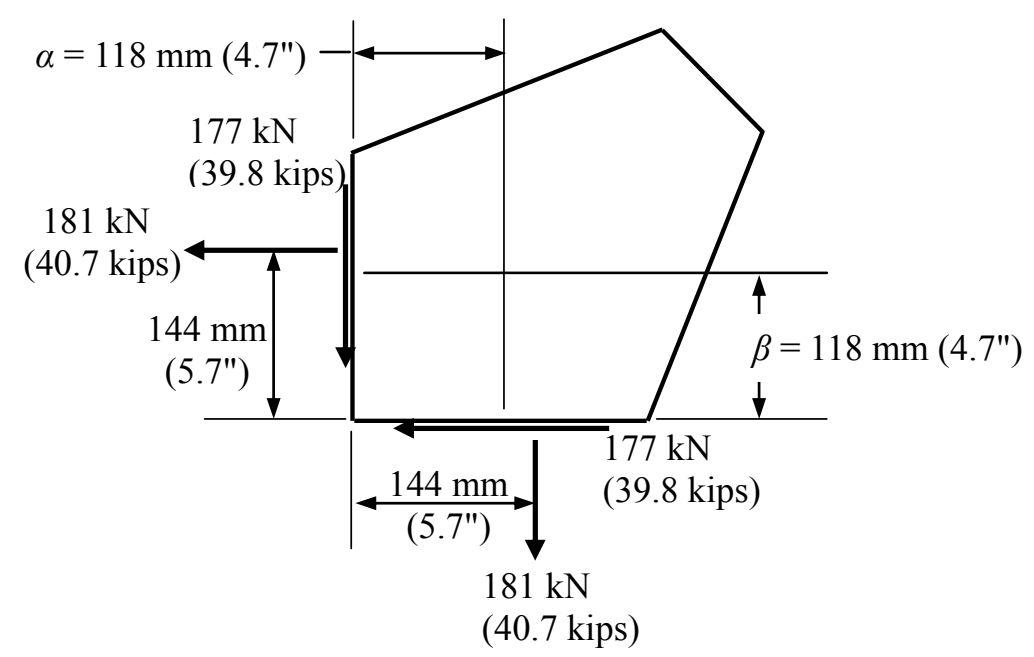

Figure 15. Resultant Shear and Tensile Forces Acting on Gusset Edges Neglecting Frame Deformation Effects

Finite element approach II - considering the effects of frame deformation on the gusset plate:

The entire braced frame shown in Figure 4 was used for the development of the finite element model as shown in Figure 16(a). A pinned condition was used at the base of the gusset-beam-column connection, as well as at the base of the beam-column connection. In this model, an additional plate was added to each of the bases in order to mitigate the stress concentrations caused by the pinned supports. 
A load increment was applied horizontally at the upper right-hand corner of the frame as shown in Figures 4 and 16(b). When the applied load reached $485 \mathrm{kN}$ (109 kips), the tensile force in the bracing element reached $507 \mathrm{kN}$ (114 kips). Meanwhile, the shear forces in the columns (the vertical elements) and beams (the horizontal elements) were developed. Note that these shear forces caused deformations of the column and the beam which in turn produced compressive stresses in the gusset plate. The model shown in Figure 16(a), therefore, considers the frame deformation effects on the gusset plate. The frame deformation effects on the gusset plate can be illustrated using the free-body diagram as shown in Figure 16(c). The applied shear force in the column and the reaction shear force in the beam cause the deflections of the column and the beam, which in turn produce compressive stresses in the gusset plate.

The von Mises stress distribution in the gusset plate obtained from this approach is shown in Figure 17. The maximum von Mises stress located at the start of the welded joint and the end of the welded joint reached $295 \mathrm{MPa}(42.8 \mathrm{ksi})$ and $266 \mathrm{MPa}(38.6 \mathrm{ksi})$, respectively. Since both of them are larger than $248 \mathrm{MPa}$ (36 ksi), yielding is expected to initiate at the start of the welded joint and the end of the welded joint. Meanwhile, as shown in Figure 18, the maximum first-principal stress, $251 \mathrm{MPa}(36.4 \mathrm{ksi})$, located at the end of the welded joint is less than $400 \mathrm{MPa}$ (58 ksi), fracturing is not expected to happen in the gusset plate.

The above finite element approaches conclude that the maximum von Mises stress obtained from Approach II is about 24\% more than that obtained from Approach I for the location at the end of the welded joint. Also, the maximum first-principal stress obtained from Approach II is about $13 \%$ more than that obtained from Approach I. The increases in stress were caused by the effects of frame deformation on the gusset plate.

Moreover, when the load applied to the bracing element reaches $507 \mathrm{kN}$ (114 kips), the shear stress $\left(\mathrm{S}_{\mathrm{xy}}\right)$ distributions along the gusset edges are shown in Figure 19, the normal stress $\left(\mathrm{S}_{\mathrm{xx}}\right)$ distribution along the vertical gusset edge is shown in Figure 20, and the normal stress $\left(\mathrm{S}_{\mathrm{yy}}\right)$ distribution along the horizontal gusset edge is shown in Figure 21. The resultant forces for the shear and tensile stresses are shown in Figure 22.

Figure 22 indicates that the resultant shear force acting along the horizontal and vertical gusset edges is $284 \mathrm{kN}$ (63.8 kips), which is about $68 \%$ larger than that obtained from the hand-calculated approach (169 kN (38.0 kips)), as shown in the design example. Also, the resultant tensile force acting on the horizontal and vertical edges is $74 \mathrm{kN}$ (16.6 kips), which is about $61 \%$ less than that obtained from the hand-calculated approach (189 kN (42.5 kips)), as shown in the design example.

Figure 22 also indicates that the resultant tensile force acting on the horizontal gusset edge is located inside the distance ' $\alpha$ ' (the distance from the face of the column flange to the centroid of the gusset-to-beam connection) and the resultant tensile force acting on the vertical gusset edge is located inside the distance ' $\beta$ ' (the distance from the face of the beam flange to the centroid of the gusset-to-column connection).

Also, referring to Figure 22, the combined effects of the factored tension and shear forces at the vertical and horizontal gusset edges can be computed (using the von Mises yield criterion [1]) as $P_{u}=\sqrt{(74 \mathrm{kN})^{2}+3(284 \mathrm{kN})^{2}}=497 \mathrm{kN}(112 \mathrm{kips})$, which is about $43 \%$ more than that obtained from hand-calculated approach (348 kN (78 kips)), which neglected the effects of frame deformation, as shown in the design example. Therefore, the above finite element approaches also conclude that neglecting the effects of frame deformation may result in significant underestimation of the combined effects of the factored tension and shear forces at the gusset edges. 


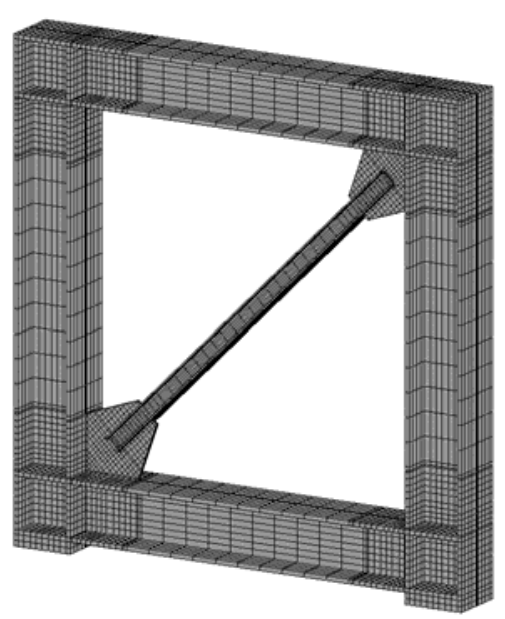

(a) Computer model

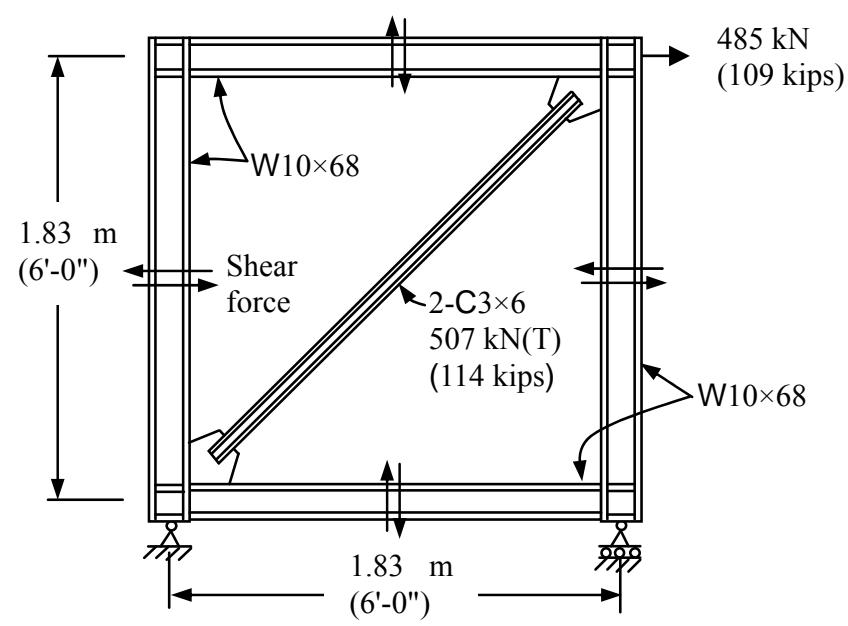

Notes: $1 \mathrm{~m}=3.28 \mathrm{ft} ; 1 \mathrm{kN}=0.2248 \mathrm{kips}$

(b) Applied load

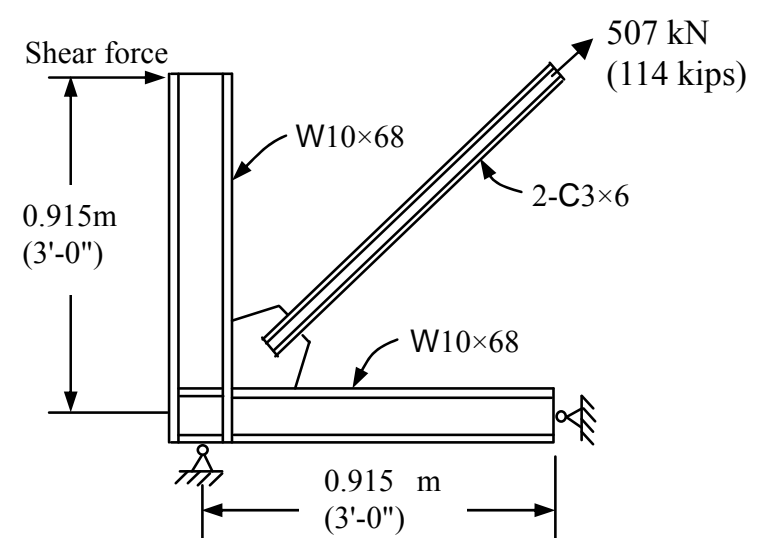

Notes: $1 \mathrm{~m}=3.28 \mathrm{ft} ; 1 \mathrm{kN}=0.2248 \mathrm{kips}$

(c) Free body diagram of the model

Figure 16. Finite Element Model Considering Frame Deformation Effects 

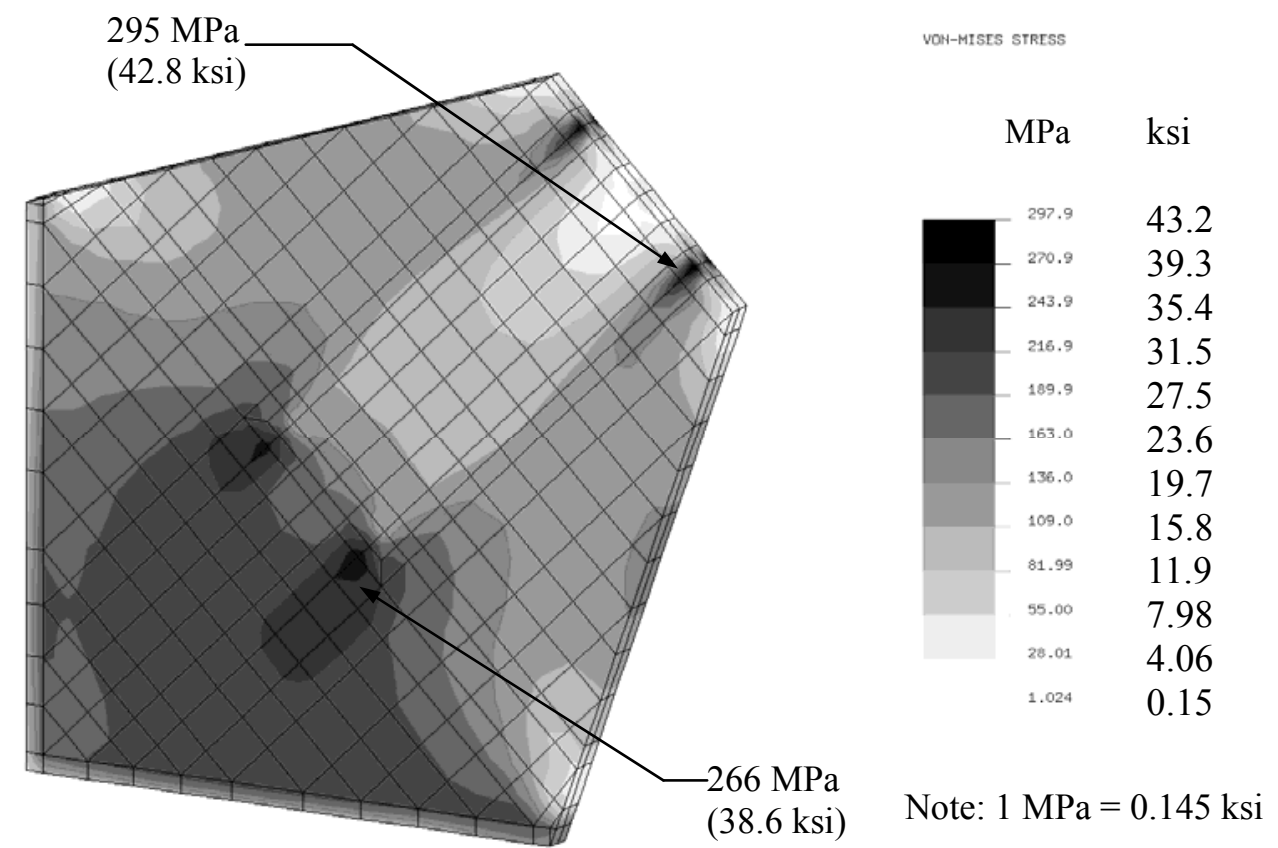

Figure 17. Von Mises Stress Distribution on Gusset Plate Considering Frame Deformation Effects
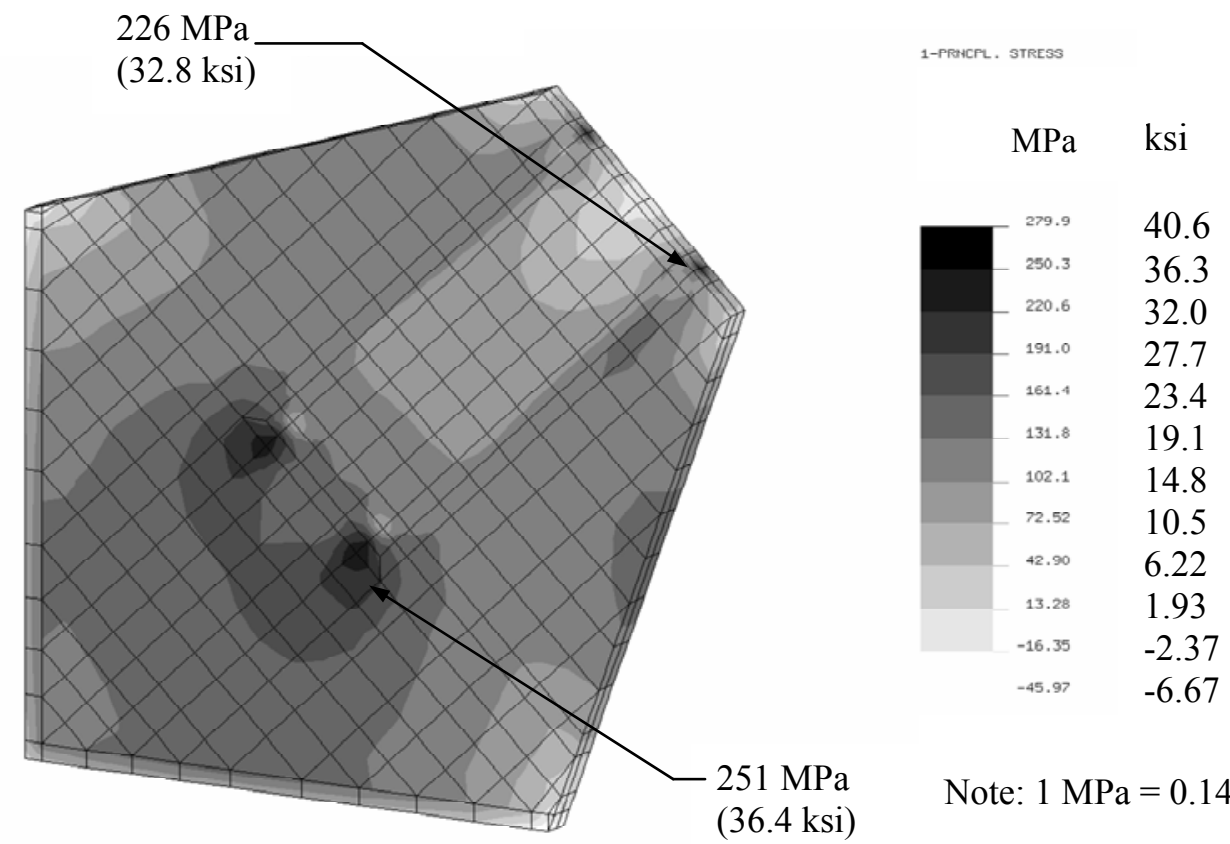

Note: $1 \mathrm{MPa}=0.145 \mathrm{ksi}$

Figure 18. First-principal Stress Distribution on Gusset Plate Considering Frame Deformation Effects 

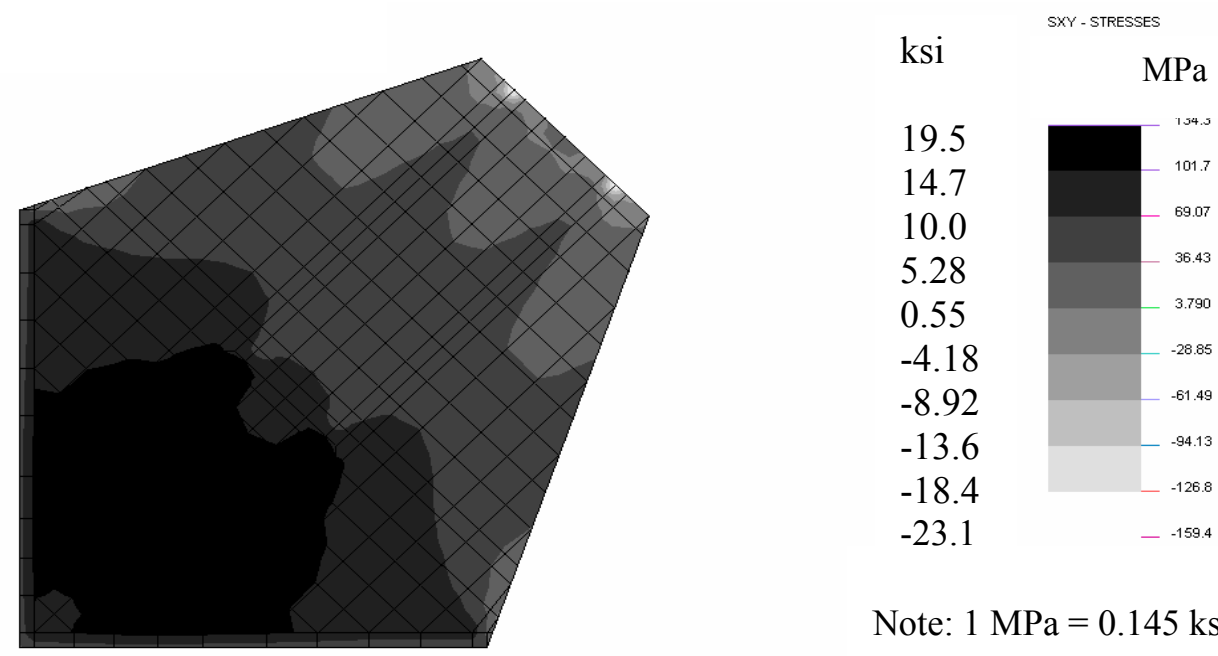

Note: $1 \mathrm{MPa}=0.145 \mathrm{ksi}$

Figure 19. Shear Stress Distributions on Gusset Edges Considering Frame Deformation Effects

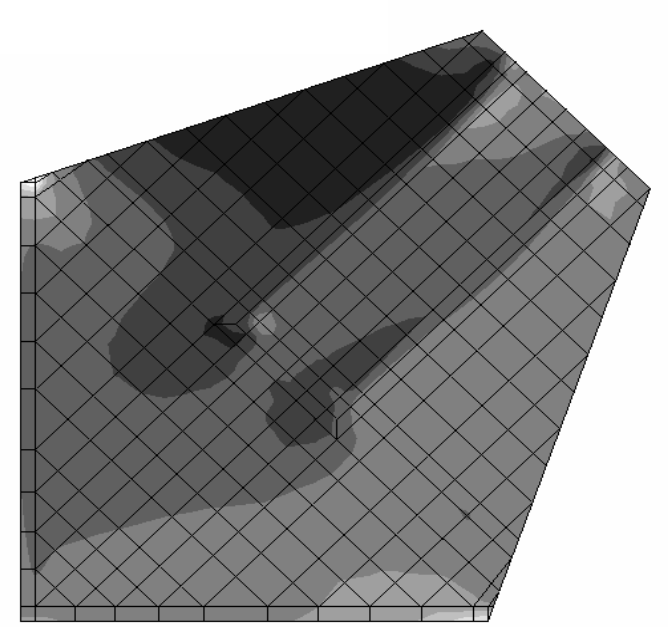

$\mathrm{ksi}$

SXX-STRESSES

23.0

18.1

13.2

8.33

3.44

$-1.45$

$-6.34$

$-11.2$

$-16.1$

$-21.0$

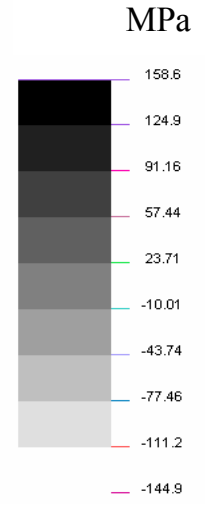

$: 1 \mathrm{MPa}=0.145 \mathrm{ksi}$

Figure 20. Normal Stress Distribution on Vertical Gusset Edge Considering Frame Deformation Effects 


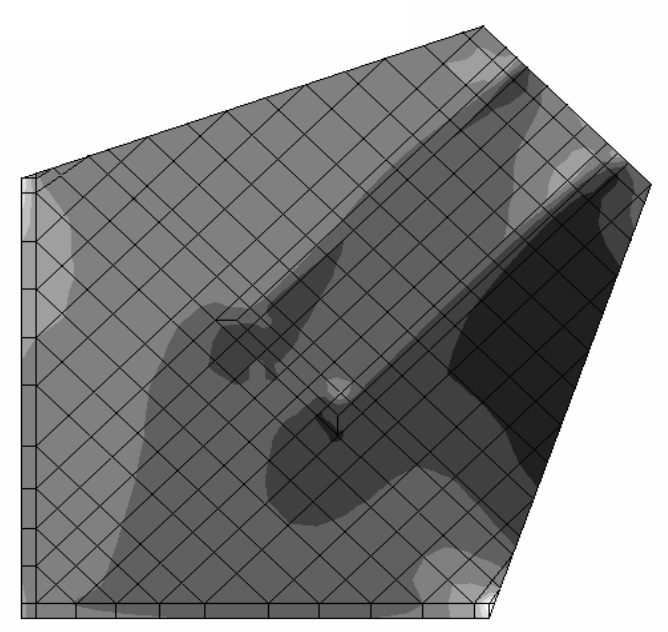

ksi

23.4

18.4

13.4

8.47

3.50

$-1.48$

$-6.45$

$-11.4$

$-16.4$

$-21.4$

Note: $1 \mathrm{MPa}=0.145 \mathrm{ksi}$

Figure 21. Normal Stress Distribution on

Horizontal Gusset Edge Considering Frame Deformation Effects

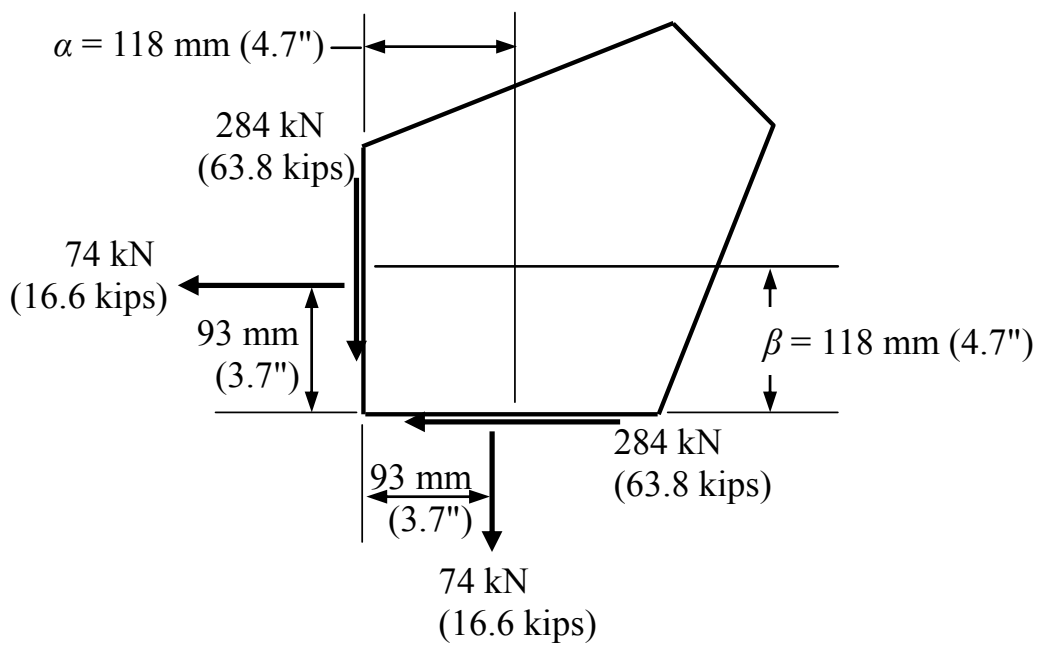

Figure 22. Resultant Shear and Tensile Forces Acting on Gusset Edges Considering Frame Deformation Effects 


\section{DISCUSSION OF THE RESULTS}

The results obtained from above indicate that significant increases in stress occurred at the end of the welded joint caused by the frame deformation effects on the gusset plate. Therefore, the hand-calculated approach, which neglects the frame deformation effects, may result in an under-design of the gusset plate connection. The following illustrates an under designed example caused by neglecting the deformation effects on the gusset plate:

Assume that ASTM A572 Grade 50 steel $\left[F_{y}=345 \mathrm{MPa}(50 \mathrm{ksi}) ; F_{u}=448 \mathrm{MPa}(65 \mathrm{ksi})\right]$ is used for the steel elements and the gusset plates as shown in Figure 4. Also assume that the factored tensile force, $P_{u}$, applied to the bracing element, is $705 \mathrm{kN}$ (158 kips) (note that the factored tensile force applied to the bracing element using A36 steel was $507 \mathrm{kN}$ (114 kips)). The required thickness of the gusset plate can be determined to be $9 \mathrm{~mm}\left({ }^{11} / 32 \mathrm{in}\right.$.) (note that the thickness for the gusset plate using A36 steel was determined to be $12 \mathrm{~mm} \mathrm{(}{ }^{15} / 32$ in.) ) using Eq. 1 (note that $R_{y}=1.1$ for ASTM A572 Grade 50 steel [10]) of the hand-calculated approach, which neglected the frame deformation effects.

The maximum first-principal stress located at the end of the welded joint of the A572, Grade 50 gusset plate, therefore, can be estimated to be about $413 \mathrm{MPa}(59.9 \mathrm{ksi})[=223 \mathrm{MPa} \times(12 \mathrm{~mm} / 9$ $\mathrm{mm}) \times(705 \mathrm{kN} / 507 \mathrm{kN})]$ using the finite element approach I which neglects the effects of frame deformation. Note that the $223 \mathrm{MPa}(32.3 \mathrm{ksi})$ is the maximum first-principal stress at the end of the welded joint of the A36 gusset plate, as shown in Figure 11, which neglected frame deformation effects. Also, the maximum first-principal stress located at the end of the welded joint of the A572 Grade 50 gusset plate, therefore, can be estimated to be about $465 \mathrm{MPa}(67.4 \mathrm{ksi})$ [ $=251$ $\mathrm{MPa} \times(12 \mathrm{~mm} / 9 \mathrm{~mm}) \times(705 \mathrm{kN} / 507 \mathrm{kN})]$ using the finite element approach II which considers the effects of frame deformation. Note that the $251 \mathrm{MPa}(36.4 \mathrm{ksi})$ is the maximum first-principal stress at the end of the welded joint of the A36 gusset plate, as shown in Figure 18, which considered frame deformation effects. Since $465 \mathrm{MPa}(67.4 \mathrm{ksi})$ is larger than $448 \mathrm{MPa}(65.0 \mathrm{ksi})$ (the specified minimum tensile strength of the ASTM A572, Grade 50 steel), fracturing may occur at the end of the weld joint of the A572, Grade 50 gusset plate. The above example indicates that the hand-calculated approach, which neglects the effects of frame deformation, may result in an under-design of the gusset plate.

Note that if A992 steel (instead of A36 steel) is used for the beam and column shown in Figure 16, the effects of frame deformation on the stress distribution in gusset plates will not change since the maximum von Mises stress in the column and beam caused by the applied force (485 kN (109 kips)) is below $248 \mathrm{MPa}$ (36 ksi, the yielding stress of A36 steel).

In order to validate the finite element procedure presented in this paper, the following investigation has been conducted:

First, a compressive load increment was applied at the end of the bracing element as shown in Figure 8(a). As the load gradually increased, the stress concentration gradually accumulated at the end of the welded joint. When the load applied to the bracing element reached $198 \mathrm{kN}$ (44.5 kips) (the approximate ultimate compressive capacity of the bracing element), the von Mises stress reached $84 \mathrm{MPa}(12.2 \mathrm{ksi})$ at the end of the welded joint. Note that there is no frame deformation effect on the gusset plate in this case.

Second, a load increment was applied horizontally toward the upper right-hand corner of the frame as shown in Figure 16(a). When the applied load reached $189 \mathrm{kN}$ (42.5 kips), the compressive force in the bracing element reached $198 \mathrm{kN}$ (44.5 kips). Meanwhile, the von Mises stress reached 103 
MPa (14.9 ksi) at the end of the welded joint. Note that the increase in von Mises stress at the end of the welded joint was caused by the effects of frame deformation on the gusset plate.

The compressive capacity of the gusset plate decreased due to the increase in von Mises stress at the end of the connected joint caused by the effects of frame deformation on the gusset plate. This result agrees with that of the full-scale tests conducted by Cheng, Grondin, and Yam [5].

\section{CONCLUSIONS}

This paper has focused on the effects of the frame deformation on welded gusset plates for diagonal bracing elements loaded in tension. A design example for a brace-beam-column gusset plate connection using the traditional hand-calculated approach, which neglects the frame deformation effects, has been given in this paper. Also, two finite element approaches have been used to investigate the adequacy of the gusset plate designed by using the hand-calculated approach. The first approach has neglected the frame deformation effects while the second approach has considered the effects.

The following conclusions are inferred from this study: (1) When a diagonal bracing member is subjected to a tensile force, the gusset plate will be stressed in tension, shear, and compression; the tension and shear stresses in the gusset plate are caused by the tensile force in the bracing member, while the compression stress in the gusset plate is caused by the deflections of the beam and column of the braced frame. (2) When the effects of frame deformation are considered, the resultant shear forces acting along the horizontal and vertical gusset edges will be increased while the resultant tensile forces acting on the horizontal and vertical gusset edges will be decreased. As a result, the combined effects of the factored tension and shear forces at the gusset edges will be increased. (3) Both the von Mises and first-principal stresses located at the end of the welded joint (which is in the Whitmore section) will be increased when the effects of the frame deformation are considered. Therefore, the traditional hand-calculated approach illustrated in this paper, which neglected the frame deformation effects, may result in an under-design of the gusset plate. (4) The increases in stress at the end of the weld joint caused by the frame deformation effects vary widely in magnitude and depend on the following factors: (a) the relative stiffness between the beam (bending stiffness), the column (bending stiffness), and the bracing element (axial deformation stiffness), (b) the configuration of the gusset plate, and (c) the degree of angle between the center line of the column and the center line of the bracing element (or the degree of angle between the center line of the beam and the center line of the bracing element).

All possible conditions of the relative stiffness, the gusset plate configuration, and the slope of the bracing element, therefore, need to be statistically studied in order to determine the maximum possible increases in stress caused by the frame deformation effects.

Due to the frame deformation effects, a rigid frame with brace-beam-column connections is highly indeterminate. Any simplifying hand-calculated approaches could be too approximate to be used for the final design of the gusset plate. The finite element analysis considering frame deformation effects, therefore, is recommended for the design of gusset plates for brace-beam-column connections. Also, this paper concludes that higher ductile structural steel (for example, A36 steel) can mitigate the frame deformation effects better than A572 Grade 50 steel. 


\section{NOTATION}

The following symbols are used in this paper:

$A_{e} \quad=$ area of the Whitmore effective section of a gusset plate

$A_{g} \quad=$ gross area

$A_{n} \quad=$ net area

$e_{b} \quad=$ one-half the depth of the beam being used

$e_{c} \quad=$ one-half the depth of the column being used

$F_{E X X}=$ weld metal tensile strength

$F_{u} \quad=\quad$ specified minimum tensile strength of the type of steel being used

$F_{y} \quad=$ specified minimum yield stress of the type of steel being used

$f_{a}=$ tension force along the gusset-to-beam (or column) interface

$f_{\text {avg }}=$ average force at the gusset-to-beam (or column) interface

$f_{b} \quad=$ in-plane bending stress along the gusset-to-beam (or column) interface

$f_{\text {peak }}=$ peak force at the gusset-to-beam (or column) interface

$f_{v}=$ shear force along the gusset-to-beam (or column) interface

$H_{u b}=$ factored shear force at the gusset-to-beam connection

$H_{u c}=$ factored axial force at the gusset-to-column connection

$l=$ length of weld

$l_{w}=$ Whitmore effective width of a plate

$P_{u} \quad=$ factored load

$R_{y} \quad=\quad$ ratio of the expected yield strength to the specified minimum yield strength of the grade of steel to be used

$t=$ thickness of a gusset plate

$t_{e} \quad=$ effective throat of fillet weld

$U=$ reduction coefficient, used in calculating effective net area

$V_{u b}=$ factored axial force at the gusset-to-beam connection

$V_{u c}=$ factored shear force at the gusset-to-column connection

$\bar{x}=$ horizontal distance from the outer edge of a channel web to its centroid

$\alpha=$ distance from the face of the column flange to the centroid of the gusset-to-beam connection

$\beta=$ distance from the face of the beam flange to the centroid of the gusset-to-column connection

$r \quad=$ distance from the working point to the centroid of the gusset plate connection

$\phi P_{n}=$ design strength

$\phi_{t} P_{n}=$ design tensile strength

$\phi R_{n}=$ design strength of the fillet weld for the gusset-to-beam (or column) flange connection

\section{REFERENCES}

[1] SEAOC, "2006 IBC Structural/Seismic Design Manual, Building Design Examples for Steel and Concrete", Structural Engineers Association of California, Sacramento, Calif., 2006.

[2] Thornton, W.A., "Bracing Connections for Heavy Construction", Engineering Journal, American Institute of Steel Construction, $3^{\text {rd }}$ Quarter, 1984, Vol. 21, No. 3, pp. 139-148.

[3] Richard, R., "Analysis of Large Bracing Connection Designs for Heavy Construction", Proceedings of the 1986 National Engineering Conference, AISC, Nashville, June 12-14, 1986. 
[4] Astaneh-Asl, A., "Seismic Behavior and Design of Gusset Plates", Steel Tips Report, Structural Steel Educational Council, Moraga, Calif., 1998.

[5] Cheng, J.J.R., Grondin,G.Y. and Yam,M.C.H., "Design and Behavior of Gusset Plate Connections", Steel Connection IV Workshop, Roanoke, VA., 2000.

[6] Whitmore, R.E., "Experimental Investigation of Stresses in Gusset Plates", Bulletin No. 16, Engineering Experiment Station, Univ. of Tennessee, TN., 1952.

[7] AISC, "Steel Construction Manual", $14^{\text {th }}$ Edition, American Institute of Steel Construction, Inc., Chicago, IL., 2011.

[8] Thornton, W.A., "On the Analysis and Design of Bracing Connections", National Steel Construction Conference Proceedings, AISC, Chicago, IL., 1991, pp. 26.1-26.33.

[9] AISC and SSEC, "Seismic Design Manual", American Institute of Steel Construction, Inc., Chicago, IL., 2006.

[10] AISC, "Seismic Provisions for Structural Steel Buildings", American Institute of Steel Construction, Inc., Chicago, IL., 2005.

[11] NISA, "NISA User's Manual", Engineering Mechanics Research Corporation, Troy, Michigan, 1998.

[12] Salmon, C.G., Johnson, J.E. and Malhas F.A., "Steel structures, design and behavior", $5^{\text {th }}$ Ed., Pearson Prentice Hall, Upper Saddle River, N.J., 2009.

[13] The Lincoln Electric Company, "The Procedure Handbook of Arc Welding", $13^{\text {th }}$ Ed., The Lincoln Electric Company, Cleveland, Ohio., 1994. 